\title{
High lightning activity in maritime clouds near Mexico
}

\author{
B. Kucienska, G. B. Raga, and R. Romero-Centeno \\ Centro de Ciencias de la Atmósfera, Universidad Nacional Autónoma de México, Circuito Exterior s/n, Ciudad Universitaria, \\ 04510 México DF, Mexico
}

Correspondence to: B. Kucienska (bkucienska@gmail.com)

Received: 23 November 2011 - Published in Atmos. Chem. Phys. Discuss.: 27 January 2012

Revised: 23 August 2012 - Accepted: 24 August 2012 - Published: 10 September 2012

\begin{abstract}
Lightning activity detected by the World Wide Lightning Location Network (WWLLN) over oceanic regions adjacent to Mexico is often as high as that observed over the continent. In order to explore the possible causes of the observed high flash density over those regions, the relationships between lightning, rainfall, vertical hydrometeor profiles, latent heating, wind variability and aerosol optical depth are analyzed. The characteristics of lightning and precipitation over four oceanic zones adjacent to Mexican coastlines are contrasted against those over the continent. The number of flashes per rainfall over some coastal maritime regions is found to be higher than over the continent. The largest number of flashes per rainfall is observed during the biomass burning season. In addition, we compare two smaller areas of the Tropical Pacific Ocean: one located within the Inter-Tropical Convergence Zone and characterized by high rainfall and weak lightning activity and the other one influenced by a continental wind jet and characterized by high rainfall and strong lightning activity. During the rainy season, the monthly distribution of lightning within the region influenced by the continental wind jet is contrary to that of rainfall. Moreover, the monthly variability of lightning is very similar to the variability of the meridional wind component and it is also related to the variability of aerosol optical depth. The analysis suggests that the high lightning activity observed over coastal Pacific region is linked to the continental cloud condensation nuclei advected over the ocean. Analysis of daily observations indicates that the greatest lightning density is observed for moderate values of the aerosol optical depth, between 0.2 and 0.35 .
\end{abstract}

\section{Introduction}

Lightning activity in the tropics is usually much higher over land than over the ocean. The contrast between land and ocean lightning density is so significant that it can be used to identify precipitation regimes. Takayabu (2006) evaluated rain-yields per flash (RPF) over the entire tropics and found that the difference in the RPF values between land and ocean was about one order of magnitude. Even though rainfall amounts over tropical oceanic zones are similar to those over land, lightning activity is much weaker in the maritime regime, which results in a higher RPF. Petersen and Rutledge (1998) calculated RPF values based on cloud-toground lightning data and found that the difference between tropical land and ocean RPF can reach two orders of magnitude. Zipser (1994) defined a similar index to RPF, a rainthunderstorm ratio, and proposed it as an indicator of the continentality of convective rainfall.

The reasons for the different rates of lightning flashes over continents and oceans are quite complex. The electric field in clouds develops as a result of the interaction between different kinds of hydrometeors (Saunders, 2008). Among the factors that influence the processes of cloud electrification are precipitation ice content (Petersen et al., 2005) and updraft velocity (Zipser and Lutz, 1994). The aforementioned factors are related, as strong updrafts lead to greater vertical cloud development and higher ice concentrations. Takayabu (2006) showed that large amounts of tall convective rainfall with precipitation top height above $-20^{\circ} \mathrm{C}$ are associated with intense updrafts and strong lightning activity. Zipser and Lutz (1994) argued that updraft velocities over tropical oceans are weaker than those over land, which implies that oceanic convective cells can hardly lift large raindrops above the freezing level or allow the formation of large particles of 
solid phase. Smaller concentrations of ice particles in maritime clouds lead to reduced lightning activity. Petersen et al. (2005) found that there is a very high correlation between precipitation ice and lightning flash density in cumulonimbus clouds and that this correlation is so similar for maritime, coastal and continental regimes, that it can be considered as regime independent.

However, not only the amount of ice is highly correlated with lightning, also the size distribution of ice particles plays an important role. Sherwood et al. (2006) showed that climatological maxima in lightning activity are associated with small effective diameter of ice crystals near the tops of cumulonimbus clouds and that the relationship is consistent over land and ocean. This finding points toward the role of aerosols in cloud electrification, since high concentrations of atmospheric aerosols may reduce the effective diameter of ice particles generated by the freezing of supercooled droplets. Recently, direct and indirect evidences on the influence of aerosol particles on lightning activity have been reported in the scientific literature (e.g. Yuan et al., 2011; Altaratz et al., 2010; Bell et al., 2009; Khain et al., 2008). It is widely agreed that the mechanisms of charge separation involve the participation of graupel, ice crystals and supercooled droplets (e.g. Takahashi, 1978; Avila et al., 1999; Saunders, 2008); therefore the impact of aerosol particles on lightning would be a consequence of their role in the formation of hydrometeors that participate in cloud electrification. Avila et al. (1999) proved that the sign of charged graupel depends on the size distribution of supercooled droplets, so it can be expected that charge separation depends not only on the concentration but also on the size distributions of atmospheric particles that serve as cloud condensation nuclei $(\mathrm{CCN})$ and that determine the cloud droplet spectra. In addition to their role in the nucleation of cloud droplets and ice crystals, high concentrations of atmospheric particles could influence lightning through a greater release of latent heat that increases updraft velocities (Kucieńska et al., 2010a; Rosenfeld et al., 2008).

The factors responsible for the contrast in lightning activity between land and ocean are not completely understood but it is clear that, on a global scale, lightning over the oceans is much less frequent than over land (Williams and Stanfill, 2002). However, there are maritime regions where lightning activity seems to be of continental type. Kucieńska et al. (2010b) presented very high number of flashes in maritime clouds that develop relatively close to the Mexican coast (up to $800-1000 \mathrm{~km}$ ). The main objective of the present paper is to study the precipitating maritime clouds that exhibit continental characteristics and propose possible reasons for their high lightning activity.

\section{Database}

The lightning activity studied in this paper was recorded by the World Wide Lightning Location Network (WWLLN) during the period 2005-2009. The WWLLN has been developed through collaborations between research institutions across the globe to provide global real-time locations of lightning discharges. The lightning is located by using the time of group arrival of the VLF $(3-30 \mathrm{kHz})$ radiation from a lightning stroke (Rodger et al., 2005). The dispersed waveform of the lightning impulse is processed at each receiving site. Each lightning stroke location requires the time of group arrival from at least five WWLLN sensors. The current network includes 40 stations which cover much of the globe and detect strokes with an efficiency larger than $10 \%(35 \%)$ for currents stronger than $\pm 35 \mathrm{kA}(-130 \mathrm{kA})$ and smaller than $2 \%$ for currents between 0 and $-10 \mathrm{kA}$. The location accuracy of WWLLN has average errors of $4.03 \mathrm{~km}$ in the north-south direction and $4.98 \mathrm{~km}$ in the east-west direction (Abarca et al., 2010). The resolution of the results presented in this study is 0.25 degrees, which is more than five times greater than the average location errors of WWLLN. The detection efficiency of WWLLN is biased toward stronger currents, which implies that the results based on WWLLN data are valid for intense lightning flashes and not necessarily for the total number of cloud-to-ground lightning flashes. Also, Abarca et al. (2011) showed that the WWLLN reproduces quite well the spatial patterns of lightning activity and Kucienska et al. (2010b) compared the monthly variability of WWLLN data and Lightning Imaging Sensor (LIS) on the Tropical Rainfall Measuring Mission (TRMM) satellite records, and found that although the detection efficiency of WWLLN is much lower than that of LIS, the monthly distributions of lightning retrieved from both datasets are very similar for continental Mexico and adjacent oceanic regions.

The surface precipitation and the profiles of hydrometeors and latent heating are obtained from the products of the TRMM, which is a joint mission between the National Aeronautics and Space Administration of the United States and the National Space Development Agency of Japan. The objectives of the TRMM are to measure rainfall and energy exchange of tropical and subtropical regions of the world (Kummerow and Barnes, 1998; Tao and Adler, 2003).

The rainfall climatology is derived from the 3B42 TRMM product based on the Adjusted Geostationary Operational Environmental Satellite Precipitation Index technique (Adler et al., 1994; Kummerow et al., 2000). It uses an optimal combination of other products and precipitation estimates to produce merged high quality infrared precipitation. The gridded estimates are on a three-hour temporal resolution and a $0.25^{\circ}$ by $0.25^{\circ}$ spatial resolution in a global belt extending from $50^{\circ}$ South to $50^{\circ}$ North. The vertical profiles of hydrometeors and latent heating are retrieved from the 2A12 TRMM algorithm which relates observed multichannel brightness 
temperatures to the hydrometeor profiles computed by cloud resolving models (Kummerow et al., 1996).

The aerosol data are retrieved from the Moderate Resolution Imaging Spectroradiometer (MODIS), which is a key instrument onboard the sun-synchronous Terra and Aqua satellites that overpass at about 10:00 a.m. (Terra) and 01:30 p.m. (Aqua) of local time. The Level-3 MODIS Atmosphere Monthly Global Product, with a resolution of one degree, was used to evaluate monthly variability of average aerosol optical depth (AOD) at $550 \mathrm{~nm}$, over the study region. Daily product MYD08_D3 was used to evaluate the impact of different ranges of AOD on lightning.

Near-surface wind speed and direction data from the SeaWinds microwave radar on the QuikSCAT (QSCAT) satellite are used for the analysis. The QSCAT mission collected data for a decade (1999-2009) in a continuous $1800-\mathrm{km}$ wide swath, covering around $93 \%$ of the ice free global oceanic surface in one day, providing high spatial and temporal resolution wind measurements over global oceans. Daily data of wind speed and direction, referenced to a height of $10 \mathrm{~m}$, were downloaded from the Center for OceanAtmospheric Prediction Studies website (http://coaps.fsu. edu/), from which wind components and convergence were calculated and averaged within $0.5^{\circ} \times 0.5^{\circ}$ latitude-longitude boxes. In this study, wind variability within the region influenced by the Tehuantepec Jet (see Fig. 1) is analyzed through the long-term monthly means of the meridional wind component and wind convergence for the period 2000-2009. All available data for the region in the daily swaths were averaged, so the resulting values do not represent a specific time of the day. The QSCAT satellite passes covered the analyzed region between 00:00 and 01:00 UTC (descending pass) and between 12:00 and 13:00 UTC (ascending pass).

\section{Results}

In order to better present our results, this section is divided into four subsections. First, the observed relationship between lightning activity and rainfall for the four oceanic regions shown in Fig. 1 is described, and the properties of maritime precipitating clouds are compared against those of continental clouds over Mexico. In the second subsection, the characteristics of the vertical profiles of hydrometeors and latent heating for the four oceanic regions and continental Mexico are presented. The third subsection is focused on the cloud characteristics in two maritime sub-regions of the Tropical Pacific: an area influenced by the Tehuantepec Jet (locally intense offshore winds in the lee of the low-elevation gap through the Sierra Madre mountain range in the Isthmus of Tehuantepec), that exhibits high values of both rainfall and lightning flashes, and an area within the Inter-Tropical Convergence Zone (ITCZ), in which clouds exhibit high rainfall and low lightning activity. And finally, the analysis of the im-

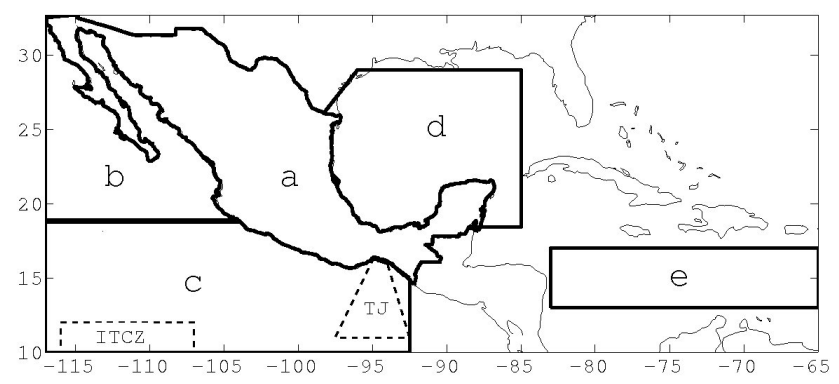

Fig. 1. Study regions: (a) Continental Mexico, (b) Subtropical Pacific, (c) Tropical Pacific, (d) Gulf of Mexico, (e) Caribbean Sea. The areas indicated by dashed lines correspond to the Tehuantepec Jet and ITCZ sub-regions that are discussed in Sect. 3.3.

pact of different ranges of aerosol optical depth on lightning is presented in the fourth subsection.

\subsection{Relationship between lightning flashes and rainfall in clouds over continental Mexico and adjacent oceanic regions}

Takayabu (2006) used TRMM databases to calculate rainyields per flash (RPF) over the entire tropics. Her results confirmed that the RPF is a reliable indicator of precipitation regimes, with a marked land-ocean contrast and intermediate values over monsoonal regions and intra-continental seas. In the present study, the number of flashes per rainfall (FPR, which is the inverse of RPF) for the four oceanic regions adjacent to Mexico (shown in Fig. 1) is analyzed. The monthly spatial variability of the number of flashes per rainfall [ $\mathrm{fl}$ $\mathrm{kg}^{-1}$ ] shows the highest values during the spring (Fig. 2). Although the maximum lightning activity occurs during the summer months (Kucieńska et al., 2010b), the FPR is higher during spring, before the onset of the rainy season (Fig. 3), when very high temperatures and moderate humidity may cause evaporation of raindrops before they reach the surface. Also, during spring there is an increased emission of particles to the atmosphere originated by biomass burning. Altaratz et al. (2010) showed that smoke aerosols from Amazonian fires have a significant influence on lightning. The results discussed in Sect. 3.3 of the present paper indicate that smoke particles increase lightning activity over the Pacific during spring.

Note in Fig. 2 that there are several regions where the value of FPR over the ocean is similar or even higher than over the continent. Next, each region is discussed separately.

\subsubsection{Gulf of Mexico (area d in Fig. 1)}

The FPR over the Gulf of Mexico presents very high values during April, May and June (Fig. 2). The spring precipitation over this area is smaller than during summer (Fig. 3), but the lightning density is quite significant (Kucieńska et al., 2010b). Note that the FPR does not exhibit a land-ocean 

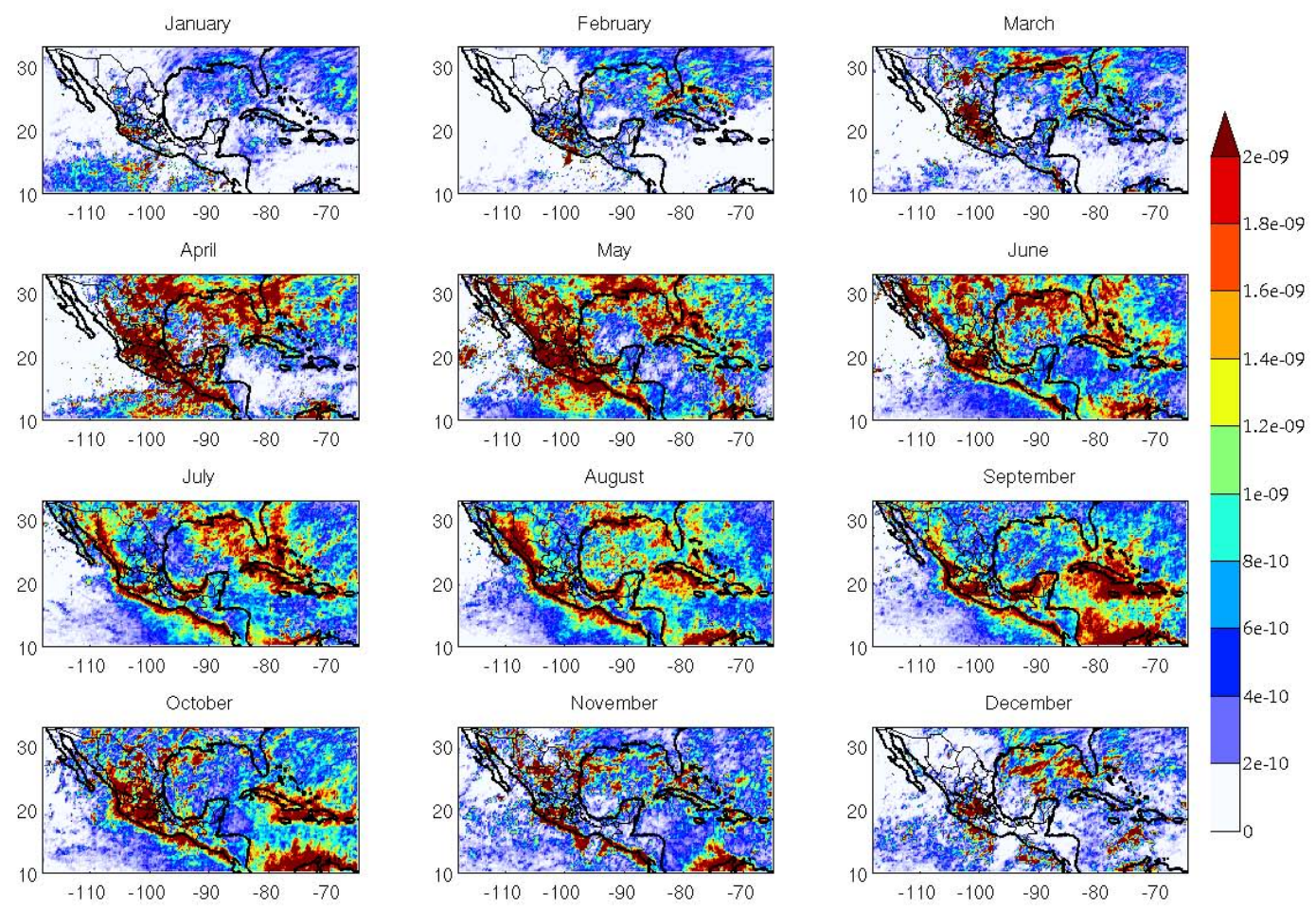

Fig. 2. Monthly distribution of flashes per rainfall [ $\left.\mathrm{fl} \mathrm{kg}^{-1}\right]$ over Mexico and adjacent oceanic regions, averaged over the years $2005-2009$.
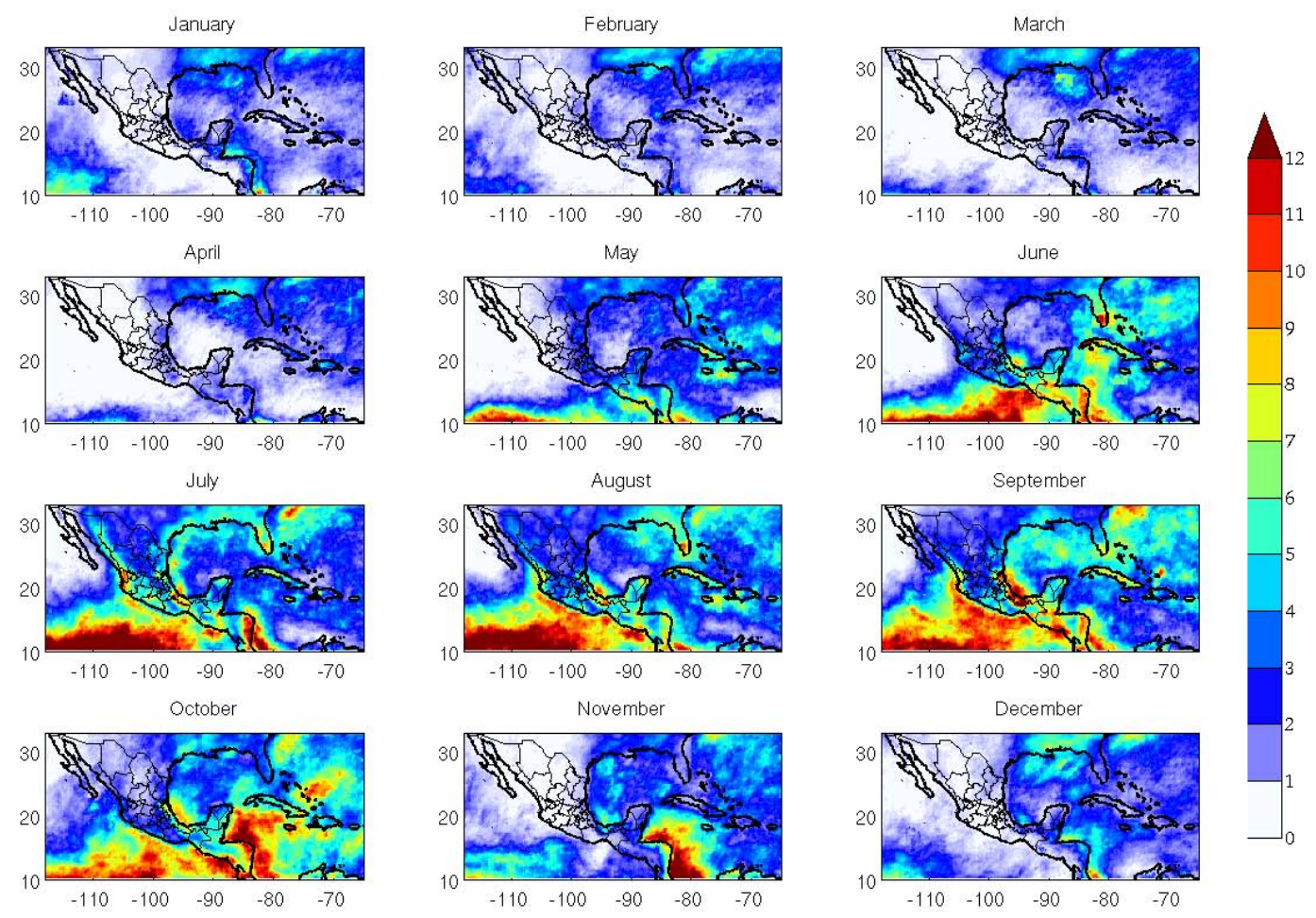

Fig. 3. Monthly distribution of rainfall $\left[\mathrm{mm} \mathrm{day}^{-1}\right]$ over Mexico and adjacent oceanic regions, averaged over the years $2005-2009$. 
contrast over the Gulf of Mexico. In fact, if the FPR is used as an indicator of precipitation regimes, as suggested by Takayabu (2006), then the precipitation over the Gulf of Mexico would be interpreted as continental.

The northern part of the Gulf of Mexico exhibits the highest values of FPR. An exceptionally strong lightning activity registered by the WWLLN over this area was already highlighted by Abarca et al. (2010), who suggested that it could be attributed to the bias of the WWLLN toward stronger flashes. Kucieńska et al. (2010b) evaluated the annual variability of the flash density [flashes $\mathrm{km}^{-2}$ ] and showed that, in the northern region of the Gulf of Mexico, more flashes are recorded over the ocean than over the land during July and August. Note that the rainfall over this part of the Gulf of Mexico is largest from July to September (Fig. 3), but the FPR decreases in September (Fig. 2). This indicates the existence of a factor which has a monthly variability that impacts lightning differently than precipitation. The monthly variability in lightning activity could be related to the wind variability. Over this particular area, during the rainy season, the onshore winds are weakest in July and August (Fig. 2 in Romero-Centeno et al., 2007), corresponding to the months that exhibit the highest lightning density (Kucieńska et al., 2010b). The decrease in the intensity of onshore winds enhances the role of land breezes in the transport of continental $\mathrm{CCN}$ toward the sea. During summer, high values of FPR are also observed at the southern part of the Gulf of Mexico, close to the coast of the states of Veracruz, Tabasco and Campeche. This area is characterized by a persistent lowlevel convergence and convection, which leads to high rainfall amounts, as shown in Fig. 3. In fact, over continental Mexico, these coastal zones present the maximum climatological precipitation. The high lightning activity observed over this region is probably related to dynamical factors.

\subsubsection{Tropical Pacific (area $\mathrm{c}$ in Fig. 1)}

This region comprises the oceanic area between $93^{\circ} \mathrm{W}$ and $117^{\circ} \mathrm{W}$ in longitude and in latitude from $10^{\circ} \mathrm{N}$ up to an arbitrary limit at $19^{\circ} \mathrm{N}$. Figure 2 shows that during spring the FPR values for the Tropical Pacific area close to the Mexican coast are similar to the continental FPR values. In summer, the FPR values over the ocean are even larger than over the land. The monthly signal of high precipitation along the Pacific coast propagates northward (Fig. 3) following the migration of the ITCZ. The mountains of the Sierra Madre del Sur are located fairly close to the coast and cause orographic forcing and locally enhanced precipitation. The complex topography prevents the high rainfall signal, that is clearly observed over the ocean, from migrating inland; therefore, the highest precipitation is observed over the coastal region. The spatial distribution of FPR (Fig. 2) is also clearly related to the topography.

Note that the area of the Tropical Pacific located farthest from the coast, within the main ITCZ (ITCZ sub-region within area c in Fig. 1), exhibits very high values of precipitation (Fig. 3) and very low values of FPR (Fig. 2). Strong lowlevel wind convergence over this zone (Fig. 6 in RomeroCenteno et al., 2007) enhances convection and precipitation but seems to have no influence on lightning activity. In contrast, the wind convergence over the areas of Tropical Pacific located close to the coast is weaker, but the lightning activity is very strong. Kucieńska et al. (2010b) suggested that the lightning activity over the Tropical Pacific areas closer to the coast is not primarily influenced by low-level convergence, but could instead be related to the continental CCN transported by the land breeze. This hypothesis is explored further in this paper.

\subsubsection{Subtropical Pacific (area $b$ in Fig. 1)}

The convection in this oceanic region, located North of $19^{\circ} \mathrm{N}$, is modulated by the North American Monsoon (Higgins et al., 2006), with precipitation observed only very close to the coast and in the Sea of Cortez during summer. The diurnal cycle of precipitation (Nesbitt et al., 2008) is related to the combination of upslope flows and sea breeze during the daytime and land breeze during the night, that results in precipitation close to the coast. The Subtropical Pacific presents the narrowest seasonal distribution of lightning among the four oceanic regions adjacent to Mexico: $95 \%$ of all the flashes occur between July and October, with the maximum observed in August (Kucieńska et al., 2010b). This seasonal cycle of lightning is clearly tied to the convection observed during the North American Monsoon. Lightning activity is confined very close to the coastline, with rainfall exhibiting the same spatial pattern (Fig. 3).

\subsubsection{Caribbean Sea (region e in Fig. 1)}

Lightning activity over the Caribbean Sea is strongest over coastal regions and the highest lightning density is observed in October (Kucieńska et al., 2010b), corresponding to the maximum precipitation (Fig. 3). However, the highest number of flashes per rainfall occurs in September (Fig. 2), when the precipitation in the coastal regions is less than $50 \%$ of the October rainfall. This suggests that the conditions that influence lightning activity over this region are not necessarily the same that influence rainfall, at least not in the same degree. Note that the maritime regions located immediately to the south of the island of Cuba exhibit FPR values similar to those observed over land. The high lightning activity in the coastal regions could again be possibly related to the advection of continental aerosol particles from the surrounding islands.

\subsection{Vertical hydrometeor profiles and latent heating}

The vertical profiles of hydrometeors and latent heating presented in this section are obtained from the 2A12 TRMM product, version 6 , retrieved from the TRMM Microwave 
Imager (TMI) records. TMI is a 9-channel passive microwave radiometer that measures brightness temperature at the frequencies 10.65, 19.35, 37, 85.5 (there is a pair of channels with vertical and horizontal polarization for each frequency) and $21.3 \mathrm{GHz}$ (one channel with vertical polarization). Its characteristics are described in detail in Kummerow et al. (1998).

The 2A12 TRMM algorithm is based on a Bayesian approach and calculates the probability of observing a particular rainfall profile at a given brightness temperature vector. The probabilities are evaluated using cloud-resolving models (Kummerow et al., 2001). The algorithm was originally designed for oceanic retrievals, since ocean surface is strongly polarized at microwave frequencies, allowing a distinction between surface and rainfall emissions. In the current version, separate algorithms for land, ocean and coastal regions are applied. The distinction between land surface and rainfall emissions for low frequency channels is a very difficult task, since the emissivities of many land characteristics are unknown. Therefore, the estimation of rainfall over land is based on the depression in the $85-\mathrm{GHz}$ brightness temperature, primarily responsive to vertically-integrated ice content. The algorithm over land assigns the $85-\mathrm{GHz}$ channel signatures to rain rates and hydrometeor profiles provided in a pre-existing database. The above relationships depend on a storm type (convective or stratiform) probability estimated by using brightness temperatures from the $10 \mathrm{GHz}, 37 \mathrm{GHz}$ and $85 \mathrm{GHz}$ channels (Golapan et al., 2010).

The 2A12 land algorithm leads to high uncertainties in rain rates over regions with significant contribution of warm precipitation. The algorithm also reveals regional and seasonal biases when compared to the TRMM 2A25 product which is based on precipitation radar data (Wang et al., 2009). It was found that TMI tends to overestimate rainfall in the tropics (Kummerow et al., 2001; Nesbitt et al., 2004).

In this subsection, the profiles of hydrometeors and latent heating over continental Mexico and adjacent oceanic regions are presented. Since TRMM 2A12 land retrievals are basically empirical, the results over continent should be interpreted with caution. The retrievals over ocean, which are the main focus of this study, have a much stronger physical basis.

In spite of the weaknesses of the 2A12 algorithm, the zonal means of precipitation water path (PWP) and near-surface precipitation water content (PWC) retrieved from the TMI are quite similar to the estimates of the TRMM 2A25 precipitation radar (PR) product (Masunaga et al., 2002), especially for the latitudes analyzed in the present study (between $10^{\circ} \mathrm{N}$ and $33^{\circ} \mathrm{N}$ ). According to the results of Masunaga et al. (2002), near-surface PWC in July is in excellent agreement with the precipitation radar product over tropical oceans and in a very good agreement over tropical land. The PWP retrieved from TMI data is $20 \%$ higher than PR estimates for latitudes between $5^{\circ} \mathrm{N}$ and $10^{\circ} \mathrm{N}$; outside of this region both datasets show excellent agreement. Also over land, PWP values retrieved from TMI match very well those of the PR product (Masunaga et al., 2002). However, direct comparison of PWC retrieved from both instruments can only be performed below the freezing level, since the precipitation radar is insensitive to ice particles (unless they are large enough to be detected by $2.2 \mathrm{~cm}$ wavelength microwaves).

The vertical profiles of hydrometeors and latent heating presented in this subsection provide additional information on the microphysical processes that take place in the precipitating clouds over oceanic regions adjacent to Mexico. The profiles of the hydrometeors (Fig. 4) are averages over the pixels with non-zero surface precipitation detected during summer months (June to September) for the five years included in the study (2005-2009). The number of averaged profiles is shown in Table 1 . Given the short observing time of individual clouds by TRMM, snapshots are captured at different phases of their development and the results must be interpreted with caution. The curves represent average profiles of water content in the different hydrometeor categories of precipitating clouds and do not correspond to the total amount of rainfall. Each panel in Fig. 4 (one for each of the 5 areas indicated in Fig. 1) contains several vertical profiles, corresponding to cloud water, precipitation water, cloud ice and precipitation ice concentrations. Vertical profiles of each hydrometeor were estimated for daytime (06:00 a.m.-06:00 p.m. LT) and nighttime (06:00 p.m.06:00 a.m. LT) and are depicted by solid and broken lines, respectively.

The vertical profiles of cloud ice and cloud water concentrations (blue and red curves in Fig. 4) are fairly similar for all the regions; the main differences can be noticed between the amounts of precipitation ice (black curve) and precipitation water (green curve). Some regions show a clear difference between day and night, such as the precipitation ice over the Subtropical Pacific (Fig. 4b) and Caribbean (Fig. 4e) regions.

The profiles averaged over continental Mexico (Fig. 4a) are shown for the purpose of comparison with maritime profiles. The information with a strong physical basis for this region is total ice amount, since it produces a clear response over land in the $85 \mathrm{GHz}$ channel. Vertical distribution of water content is based on a limited number of profiles which were carefully selected so that the rain rate retrieved from TMI should be consistent with ground measurements. Among the analyzed regions, continental Mexico (Fig. 4a) exhibits the greatest amounts of precipitation ice (black curve), with a maximum located $6 \mathrm{~km}$ above the surface, and the largest height range of coexistence of precipitation ice and cloud water content, relevant for charge separation and lightning production. There is slightly more precipitation ice during nighttime (06:00 p.m.-06:00 a.m. LT) than during the day. This is in agreement with the diurnal cycle of lightning flash density over continental Mexico, since the maximum lightning activity is observed between 06:00 p.m. and 09:00 p.m. (Kucieńska et al., 2010b). The corresponding 

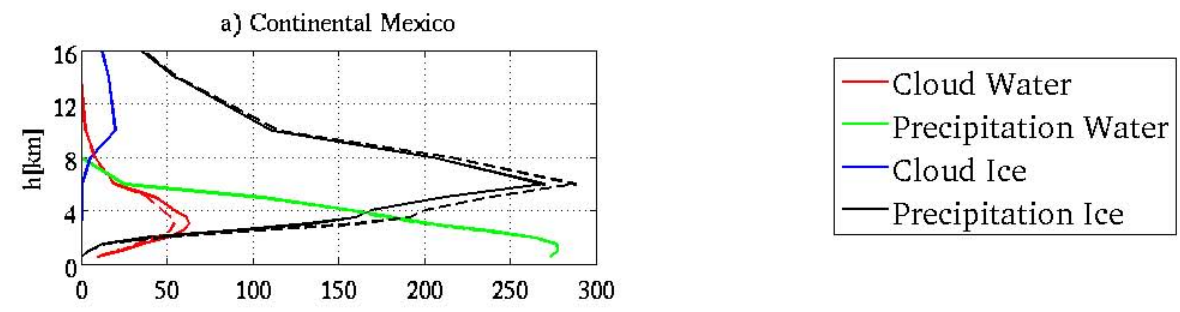

b) Subtropical Pacific
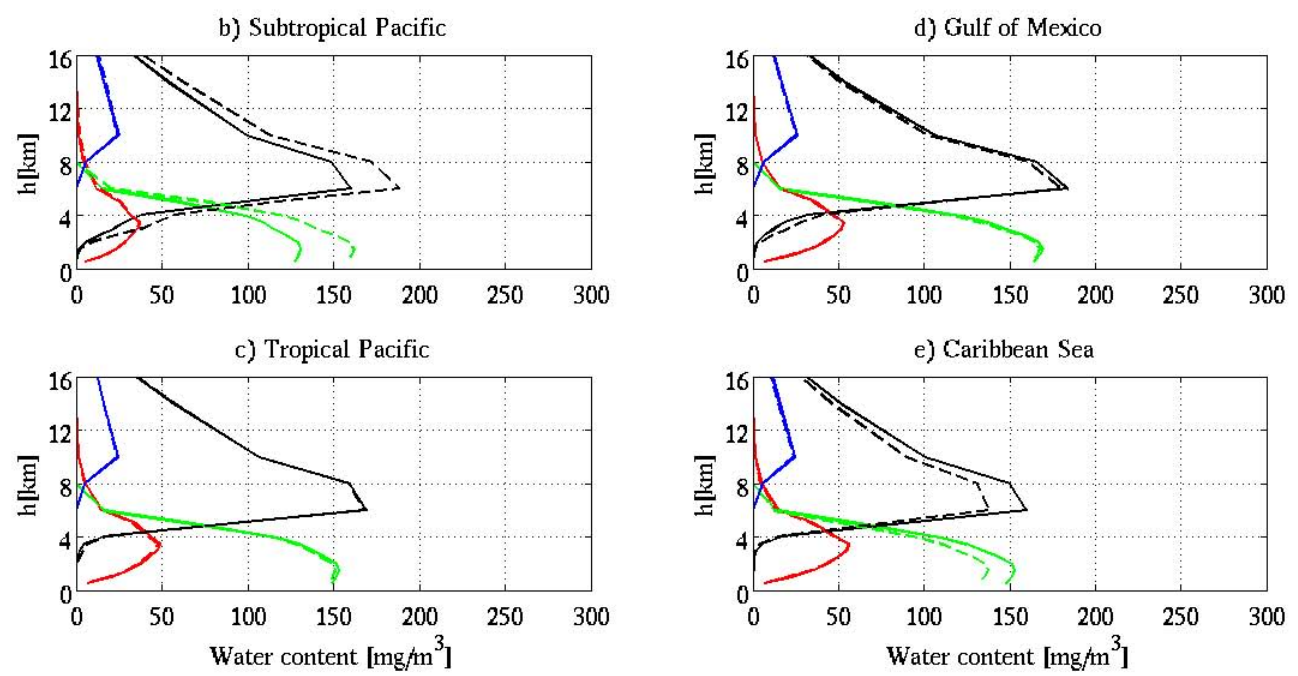

Fig. 4. Vertical profiles of hydrometeors in precipitating clouds averaged over four summer months (June to September) for the period 20052009, and spatially averaged over the regions shown in Fig. 1. Solid lines correspond to daytime profiles (06:00 a.m.-06:00 p.m.) and dashed lines correspond to nighttime profiles (06:00 p.m.-06:00 a.m.).

Table 1. Number of hydrometeor profiles registered during day (06:00 a.m.-06:00 p.m.) and night (06:00 p.m.-06:00 a.m.) that were averaged over five study regions. Only the pixels with nonzero surface precipitation were taken into account.

\begin{tabular}{lrrrrr}
\hline Region & $\begin{array}{r}\text { Cont. } \\
\text { Mexico }\end{array}$ & $\begin{array}{r}\text { Caribbean } \\
\text { Sea }\end{array}$ & $\begin{array}{r}\text { Gulf of } \\
\text { Mexico }\end{array}$ & $\begin{array}{r}\text { Subtrop. } \\
\text { Pacific }\end{array}$ & $\begin{array}{r}\text { Tropical } \\
\text { Pacific }\end{array}$ \\
\hline Day & 615134 & 232799 & 558908 & 158431 & 1912844 \\
Night & 1202671 & 147558 & 349204 & 147120 & 1574607 \\
\hline
\end{tabular}

vertical profile of the latent heating (Fig. 5a) exhibits a clear maximum at about $7 \mathrm{~km}$, corresponding to the level of maximum ice formation at a temperature of about $-12^{\circ} \mathrm{C}$.

The maritime regions adjacent to Mexico represent primarily the characteristics of areas located far from the coastlines, but also include the coastal areas (see Fig. 1), which should be taken into account when interpreting the vertical profiles of hydrometeors. The largest concentrations of precipitation ice are observed over the Subtropical Pacific and the Gulf of Mexico. Recall that rainfall and lightning over the Subtropical Pacific occur only very close to the coast and the profiles of the hydrometeors should be interpreted as profiles representative of coastal regions. A large precipitation ice amount and a significant interval of coexistence of the precipitation ice and supercooled cloud water, indicate that the processes involved in charge separation in these clouds could be similar to those that occur in continental clouds. The highest lightning activity over this region occurs at night and during the early morning; it is associated with land breeze periods (Nesbitt et al., 2008; Kucieńska et al., 2010b) and corresponds to the maximum in the concentration of precipitation ice at night (Fig. 4b). The shape of the latent heating profile, shown in Fig. 5b, is also similar to that of continental Mexico, although the absolute values are much smaller.

The Tropical Pacific zone covers the areas located both close and far away from the coast (see Fig. 1) and probably this is the reason for the absence of diurnal cycle in ice amount, shown in Fig. 4c. However, Kucieńska et al. (2010b) showed that lightning over this region has a diurnal cycle, so identical profiles of precipitation ice for day and night in Fig. $4 \mathrm{c}$ may be due to algorithm deficiencies. The profile of latent heating (Fig. 5c) is similar to that of the Subtropical Pacific, but the peak corresponding to condensation is larger, which could mean greater participation of warm-rain processes occurring in the clouds that form far from the coast and are less influenced by continental CCN.

Vertical hydrometeor profiles over the Gulf of Mexico (Fig. 4d) are averaged over the areas close and away from the coast, but most of the rainfall occurs basically over the 


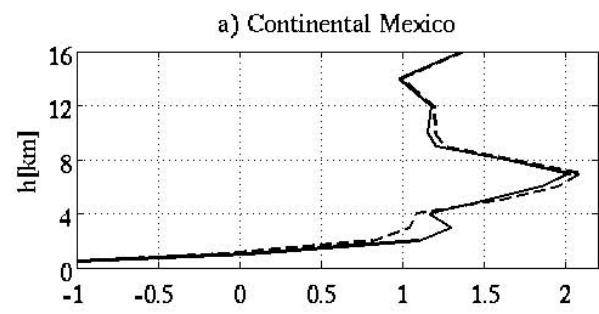

b) Subtropical Pacific

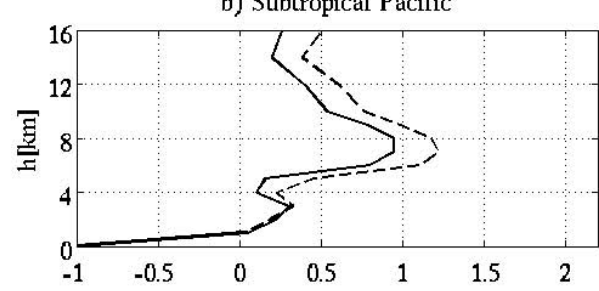

c) Tropical Pacific

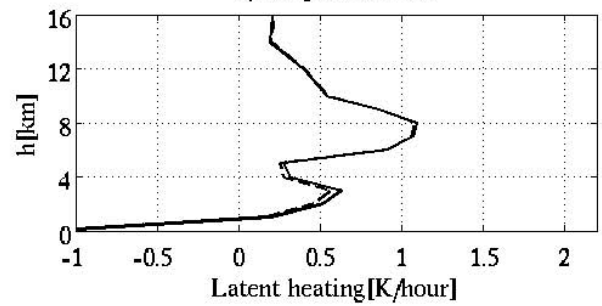

Fig. 5. Similar to Fig. 4 but for the latent heating.

coastal areas (see Fig. 3). The precipitation ice profile is very similar to that of the Tropical Pacific and there is almost no difference between day and night. The latent heating peak corresponding to condensation in Fig. 5d is quite significant, indicating that over the Gulf of Mexico warm rain processes could play a noteworthy role in the formation of precipitation.

The hydrometeor profiles over the Caribbean Sea (Fig. 4e), are averaged over areas mainly located away from the coastlines, or at least not in their immediate vicinity (see Fig. 1), and probably this is the reason for less precipitation ice over this zone than over the other maritime regions analyzed in this study. The concentrations of precipitating hydrometeors are larger during daytime (06:00 a.m.-06:00 p.m.) than during the night (06:00 p.m.-06:00 a.m.). Because of the location of the Caribbean Sea, diurnal cycles of rainfall and lightning are not modulated by land and sea breezes, and $\mathrm{Ku}-$ cieńska et al. (2010b) showed that the diurnal distribution of lightning over the Caribbean Sea is quite uniform. The diurnal cycle of precipitation ice shown in Fig. 4e is not correlated with the diurnal cycle of lightning (Kucieńska et al., $2010 \mathrm{~b}$ ) and it could be a result of TRMM 2A12 algorithm uncertainties. Note in Fig. 5e that the latent heating maxima corresponding to the formation of liquid and solid phases are comparable in magnitude. The role of warm rain processes in the development of precipitation at the surface seems to be greatest over the Caribbean Sea among all the regions considered. However, since the latent heat of condensation is about seven times larger than that of freezing, most of the precipitation over this area forms by mixed-phase processes, and the role of precipitation ice is clearly dominant, as shown in Fig. 4e.

\subsection{Lightning activity in clouds over the Gulf of Tehuantepec and the ITCZ in the eastern Tropical Pacific}

Kucieńska et al. (2010b) hypothesized that the high lightning activity observed over the Mexican coastal areas over the Pacific Ocean is linked to the advection of continental aerosol particles over the ocean. This hypothesis will be explored by comparing two sub-regions over the Pacific Ocean: a coastal sub-region that presents high rainfall and high lightning density (hereafter referred as Tehuantepec sub-region) and a sub-region within the ITCZ that exhibits high rainfall but low lightning density. These two sub-regions are indicated by dashed lines in Fig. 1 and are characterized by high sea-surface temperatures throughout the year (Fig. 7 in Romero-Centeno et al., 2007).

The wind and precipitation patterns in the Tehuantepec sub-region are influenced by the complex topography and are determined by meso- and synoptic-scale systems related to the latitudinal shift of the ITCZ, the presence of easterly waves and other tropical waves (such as mixed 
Rossby-gravity and Kelvin waves), the intrusion of midlatitude dry and cool continental air masses, the occurrence of tropical cyclones, the seasonal variability of the high pressure systems over the North Pacific and Atlantic basins, and the land-sea breezes, among other processes. The region exhibits low variability in terms of temperature (less than $1 \mathrm{~K}$ between ridges and troughs of easterly waves in the mid-tolower troposphere, Petersen et al., 2003) and humidity (less than $10 \%$ difference) during the rainy months.

Most of the precipitation and lightning observed in the region is associated with deep convection, with cloud tops much higher than the freezing level, located on average around $4.7 \mathrm{~km}$ (Short and Nakamura, 2000), and presenting very little variability throughout the year. Chui and Chang (2000) present cloud-top heights above $6 \mathrm{~km}$ in our region of study, for the average of June-July-August, with less than $10 \%$ of the clouds showing tops below $3 \mathrm{~km}$. Nesbitt et al. (2000) evaluated the precipitation features in several regions of the globe based on TRMM data and, relevant to our study, show results for the eastern North Pacific. Precipitation features with ice scattering showed a $5.5 \mathrm{~km}$ median value of the maximum height of the $30-\mathrm{dBz}$ reflectivity and $231 \mathrm{~K}$ median polarization corrected temperature (related to the size of the ice hydrometeors). Petersen et al. (2003) analyzed radar observations in a ship located in the region during the EPIC project in September-October 2001 and the results indicated that the tail in the 30-dBZ frequency extends to heights exceeding $11 \mathrm{~km}$, coinciding with the passage of the northerly phase of easterly waves.

The Tehuantepec sub-region is under the influence of the Tehuantepec Jet: northerly winds funneled through the narrow mountain pass across the Isthmus of Tehuantepec that can reach gale ( $\geq 34 \mathrm{kt})$, storm ( $\geq 48 \mathrm{kt}$ ) or even hurricane ( $\geq 64 \mathrm{kt}$ ) force (Brennan et al., 2010), and have a large impact on cooling the sea surface temperature of the Gulf of Tehuantepec (e.g. Barton et al., 1993). The jet is clearly identifiable by satellite remote observations, in particular from the NASA scatterometers NSCAT and QSCAT (Chelton et al., 2000, 2004).

Tehuantepec wind jets can last from several hours to a few days; they are more frequent and intense during fall-winter, associated with cold fronts of mid-latitude origin that move southward and penetrate into the Gulf of Mexico (Schultz et al., 1997), and they decrease in number and intensity towards the summer season in response to a weaker pressure gradient across the Isthmus of Tehuantepec. However, due to the intensification and westward elongation of the North Atlantic Subtropical High by mid-summer, there is a slight increase of these events during this time of the year (Romero-Centeno et al., 2003). A bimodal behavior is also observed in the annual cycle of precipitation in southern Mexico, showing minimum precipitation rates in winter, maximum in June and September, and a rainfall decrease in July-August, when a reduction in the number of tropical cyclones generated in the eastern North Pacific also occurs (Magaña et al., 1999).
The Jet of Tehuantepec advects aerosol particles from the continent to the ocean. The concentration of particles of anthropogenic origin is very high over this region, as one of Mexico's largest oil refineries is located on the coast of the Gulf of Tehuantepec, in the town of Salina Cruz. The Jet of Tehuantepec is responsible for the advection and dispersion of particles over very large oceanic areas. Baumgardner et al. (2005) found that the concentration of condensation nuclei over the ocean, about $700 \mathrm{~km}$ south from the coastline, was four to five times higher when winds were from the continent than when winds were from the Central Pacific. Moreover, Kucieńska et al. (2010b) showed that during summer the signal of high lightning density over the Gulf of Tehuantepec extends more to the south than over other zones along the Pacific coastline. Changes in the intensity of the Jet of Tehuantepec modulate monthly rainfall variability near the coast. Kucieńska et al. (2012) noticed that the monthly variability of lightning over the coastal area close to the town of Salina Cruz is related to the wind variability: the midsummer months, when the Jet of Tehuantepec strengthens, correspond to those with highest lightning density. An interesting feature of this region is that when the Tehuantepec Jet of northerly flow strengthens during July and $\mathrm{Au}-$ gust, it inhibits the moisture advection from the Pacific resulting in a decrease in rainfall over the coastal zones, the so-called mid-summer drought, that is also observed further inland (Magaña et al., 1999; Curtis, 2004; Romero-Centeno et al., 2007). Therefore, the region under study may be one of a few regions in the world where the changes in wind intensity have opposite effects on rainfall and lightning.

The ITCZ sub-region (see Fig. 1) is an area with very high rainfall and very low lightning activity (compare Figs. 2 and 3 ) and it is reasonable to expect that the clouds that form over this sub-region must be quite different than those developing in the Tehuantepec sub-region.

The profiles of hydrometeors over the Tropical Pacific, shown in Fig. $4 \mathrm{c}$ and discussed in the previous section, were averaged over a very large area where coastal clouds and typical maritime clouds are present. The hydrometeor profiles of the Tehuantepec (Fig. 6a) and ITCZ (Fig. 6b) sub-regions are presented separately for comparison, since they can be considered as two different regimes.

The basic difference between the two regimes is the amount of precipitation ice: Tehuantepec clouds exhibit more precipitation ice than ITCZ clouds. Note also that the amount of precipitation water is greater for the Tehuantepec clouds (Fig. 6). This does not mean that the total rainfall over the Tehuantepec sub-region is greater than that over the ITCZ; it only means that an average instantaneous profile of the ITCZ sub-region exhibits less precipitating water, which implies smaller precipitation rates.

The profile of precipitation ice over the Tehuantepec sub-region indicates larger concentrations during the day (06:00 a.m.-06:00 p.m., solid curve in Fig. 6a), whereas over the ITCZ sub-region there is more ice at night (06:00 p.m.- 
a) Tehuantepec Jet sub-region

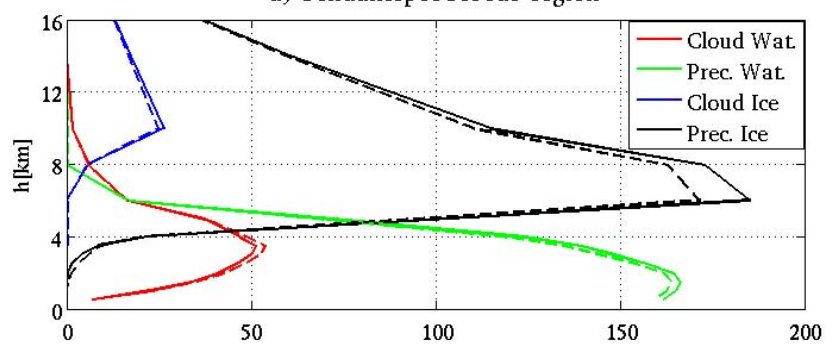

b) ITCZ sub-region

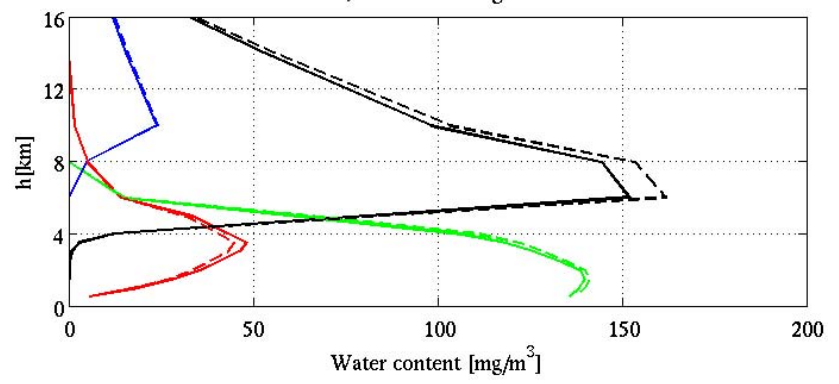

Fig. 6. Hydrometeor vertical profiles of precipitating clouds averaged over four summer months (June to September) for: (a) Tehuantepec Jet and (b) ITCZ sub-regions over the Pacific Ocean. Solid lines correspond to daytime profiles (06:00 a.m.-06:00 p.m.) and dashed lines correspond to nighttime profiles (06:00 p.m.06:00 a.m.).

06:00 a.m., dashed curve in Fig. 6b). The precipitation ice is believed to be proportional to the lightning density (Petersen et al., 2005); therefore, different diurnal distributions of lightning are to be expected for the two sub-regions. The diurnal cycles of lightning densities for both sub-regions are presented in Fig. 7 in terms of the percentage of daily flashes observed during three-hour intervals. The highest lightning activity over the Tehuantepec sub-region (Fig. 7a) is observed between 03:00 a.m. and 09:00 a.m. and the lowest one between 03:00 p.m. and 06:00 p.m. Baumgardner et al. (2006) measured the highest frequency of land breeze between 05:00 a.m. and 09:00 a.m. and the minimum between 02:00 p.m. and 06:00 p.m.. The diurnal distribution of lightning over the Tehuantepec sub-region is clearly related to the cycle of the land breeze that increases convergence over the ocean and advects aerosol particles from the continent. In contrast, the diurnal cycle of lightning over the ITCZ subregion (Fig. 7b) is much more uniform, although a bimodal distribution with maxima at 09:00 a.m. and 09:00 p.m. is noticeable.

The profiles of latent heating for the Tehuantepec and ITCZ regimes also exhibit significant differences (Fig. 8). Latent heating corresponding to the level of maximum ice formation is about $20 \%$ larger for the Tehuantepec subregion than for the ITCZ one. Also note that the latent heating associated with the formation of cloud droplets is larger for the Tehuantepec regime. Over the Tehuantepec sub-region, a) Tehuantepec Jet sub-region

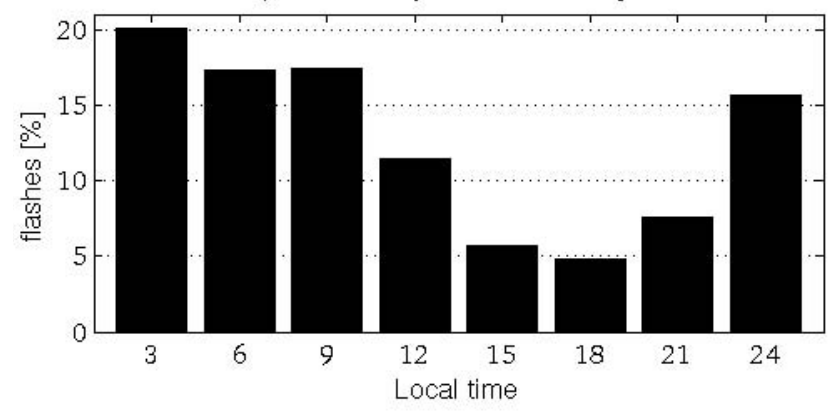

b) ITCZ sub-region

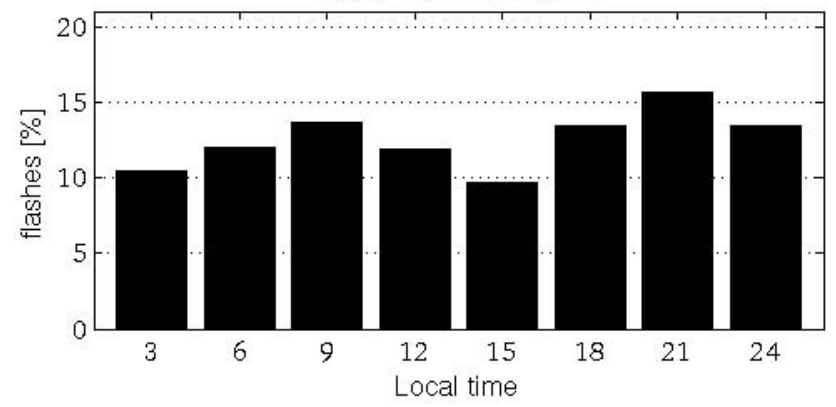

Fig. 7. Diurnal cycles of flashes in the (a) Tehuantepec Jet and (b) ITCZ sub-regions over the Pacific Ocean. The three-hour averages are centered at the indicated hours.

more liquid phase forms at night, while solid phase formation is greater during daytime. The opposite situation occurs over the ITCZ sub-region (Fig. 8).

Kucieńska et al. (2012) noticed that the monthly variability of lightning at the coast of Oaxaca state is similar to that of the Jet of Tehuantepec. Here, this relation is explored by comparing monthly distributions of lightning, precipitation, winds and AOD. We focus on monthly distributions of these variables over the Gulf of Tehuantepec for a very specific reason. We hypothesize that the increase of lightning during mid-summer is related to the intensification of the Jet of Tehuantepec during July and August. The variability of the Jet of Tehuantepec exhibits a clear monthly pattern which has an impact on the monthly variability of precipitation. The decrease of precipitation during July and August over this region (so-called mid-summer drought) is related to the intensification of the Jet of Tehuantepec which causes a reduction in moisture over coastal areas and displaces convergence areas away from the coast (Romero-Centeno et al., 2007). Anticorrelated monthly patterns of both wind velocity and precipitation repeat yearly, although there are some years when the influence of other phenomena (e.g. ENSO) somewhat modify this pattern. In this study we hypothesize that the monthly variability of the Jet of Tehuantepec has an influence not only on the monthly pattern of precipitation but also on that of lightning. 

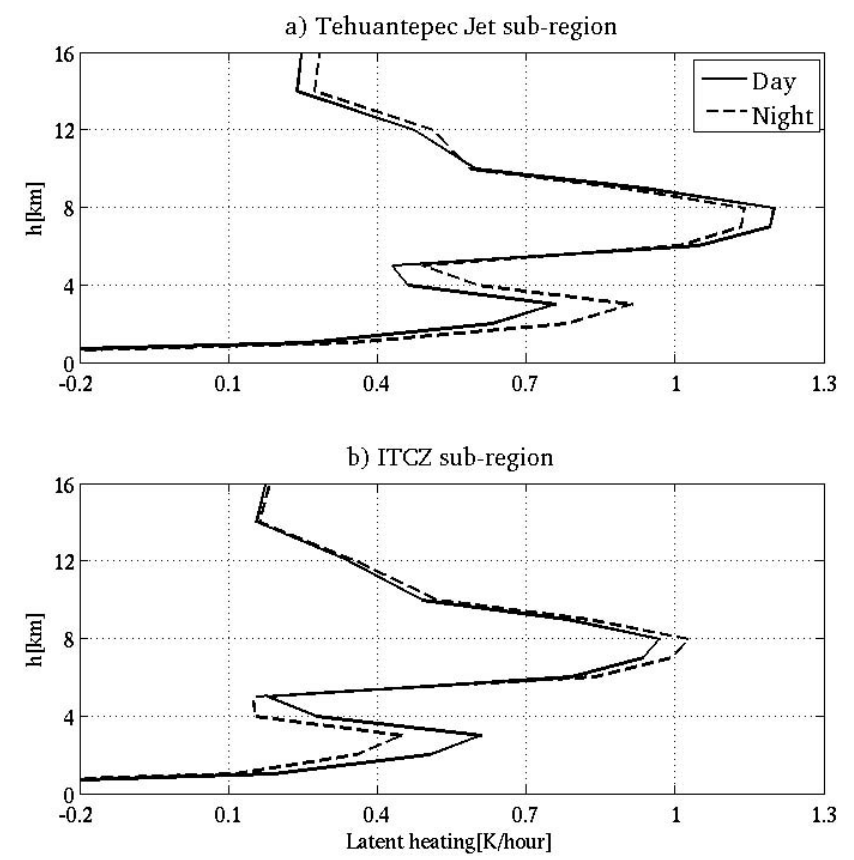

Fig. 8. Vertical profiles of the latent heating averaged over four summer months (June to September) for the period 2005-2009, and spatially averaged over the sub-regions: (a) Tehuantepec Jet and (b) ITCZ. Solid lines correspond to daytime profiles (06:00 a.m.06:00 p.m.) and dashed lines correspond to nighttime profiles (06:00 p.m.-06:00 a.m.).

A deep analysis of the influence of the mid-summer strengthening of the Jet of Tehuantepec on the low-level circulation over the northeastern Tropical Pacific is included in Romero-Centeno et al. (2007). During the seven-year period (1999-2005), the percentage of occurrence of northerly winds over the Gulf of Tehuantepec always increased in July or (and) August. Also, the wind velocity increased during the mid-summer period. Furthermore, Romero-Centeno et al. (2007) analyzed the relationship between the Jet of Tehuantepec and the moisture fluxes, horizontal divergence and precipitation over the zone where the mid-summer drought occurs, as well as the influence of the jet on zonal winds over the northeastern Tropical Pacific (10-15 ${ }^{\circ}$ N, 115$\left.95^{\circ} \mathrm{W}\right)$. They found that along with the mid-summer intensification of the Jet of Tehuantepec, there is a shift in the low-level wind circulation over the northeastern Tropical Pacific, which shows an eastward (toward the coast) orientation in June and September and a westward (off the coast) orientation in July and August. This reversal of zonal winds during mid-summer changes the direction of the moisture fluxes (off the coast during July and August) and shifts convergence areas away from the coast. These changes in circulation contribute to the decrease of precipitation. Using daily observations, Romero-Centeno et al. (2007) evaluated the synoptic scale variability of wind speed and direction with precipitation and found a significant correlation at this time-scale. The a) Tehuantepec Jet sub-region

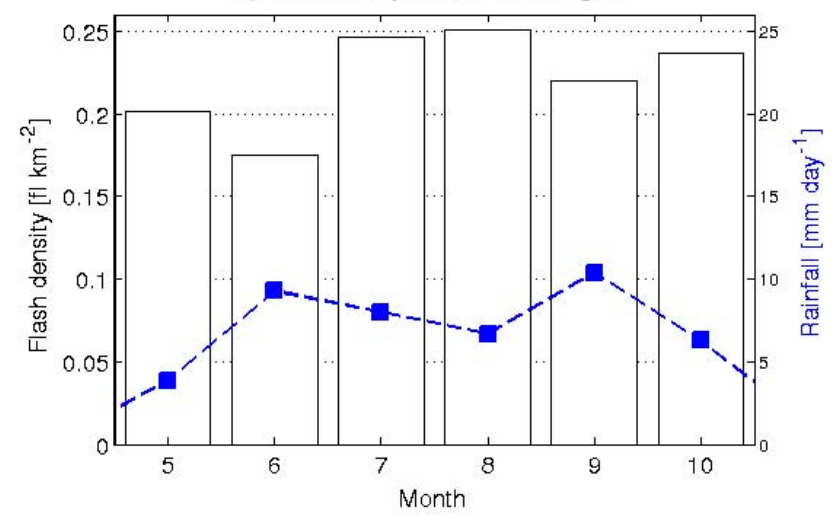

b) ITCZ sub-region

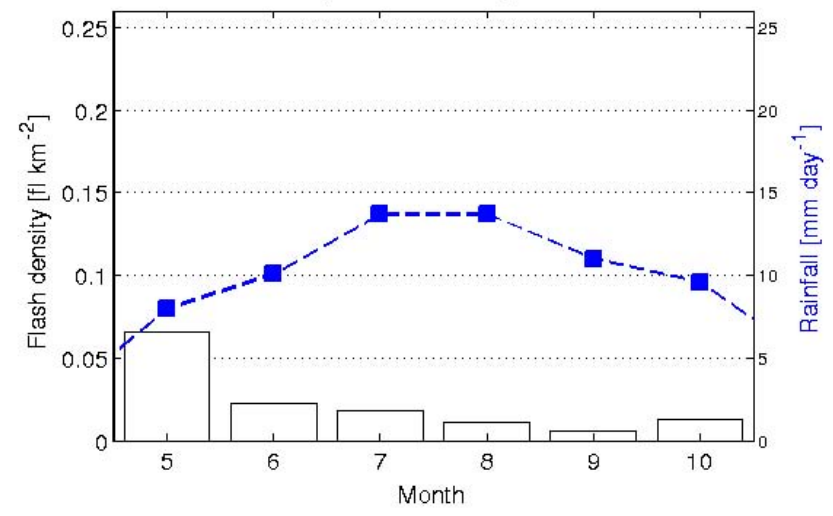

Fig. 9. Monthly variability of lightning flash density (bars) and precipitation (blue line) over the (a) Tehuantepec Jet and (b) ITCZ subregions during rainy season.

correlation between zonal winds over the northeastern Tropical Pacific and precipitation over the mid-summer drought region is 0.84 .

Monthly variability of lightning densities for the Tehuantepec and ITCZ regions during the rainy season, and the variability of rainfall, averaged over the years 1998-2009, are shown in Fig. 9. Lightning density over the ITCZ subregion (Fig. 9b) is about one order of magnitude smaller than that over the Tehuantepec sub-region (Fig. 9a). Note that the monthly distribution of lightning in the ITCZ regime exhibits a maximum in May, which is the month with lowest rainfall within the rainy season.

The monthly distribution of lightning over the region influenced by the Jet of Tehuantepec is remarkable since the variability of lightning is contrary to that of rainfall. There is a dramatic increase in rainfall from May to June over the Tehuantepec regime; however, note that lightning flash density decreases from May to June (Fig. 9a). Rainfall over the Tehuantepec sub-region decreases from June to July due to the onset of the mid-summer drought, but the lightning density increases for the same period (Fig. 9a). Note that the 


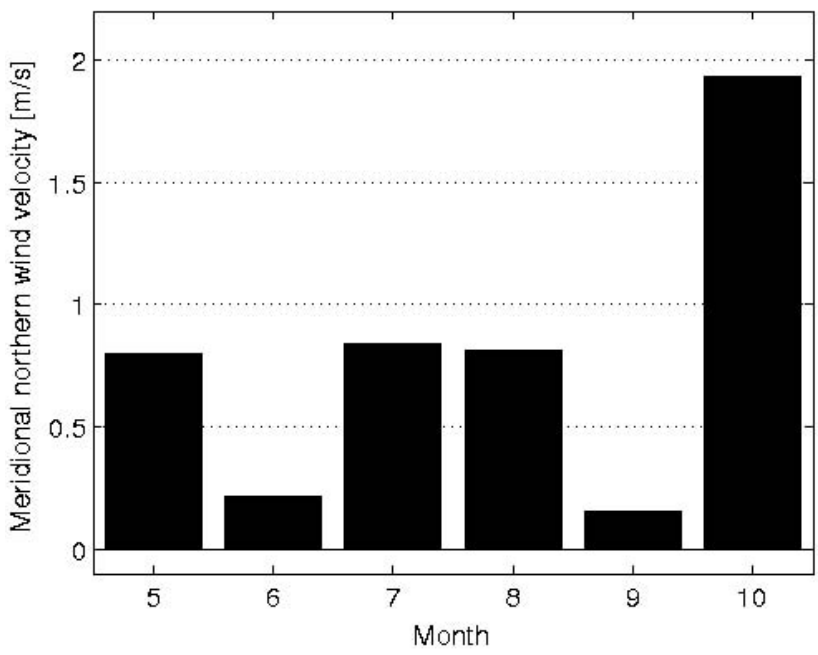

Fig. 10. Monthly variability of meridional northern wind velocity averaged over the Tehuantepec Jet sub-region during the rainy seasons of years 2000-2009.

highest lightning density is observed during July and August, months corresponding to the mid-summer drought. In September, rainfall increases, but lightning density decreases (Fig. 9a), while in October there is a decrease in rainfall and an increase in lightning activity.

The region studied is unique because of the presence of a phenomenon which seems to have opposite effects on precipitation and lightning. The influence of the Jet of Tehuantepec on lightning is quite complex, since the same factors that have a negative effect on precipitation (reduced moisture and convergence) are supposed to have a negative effect on lightning (reduced moisture may lead to lower ice content and less convergence would result in lower updrafts). However, the increase of lightning during the mid-summer indicates the existence of another factor which seems to have a different impact on lightning than on precipitation. We hypothesize that this factor is the presence of continental aerosols transported by the Jet of Tehuantepec over the maritime regions.

The monthly variability of the meridional wind component (Fig. 10) is analyzed in order to explore the hypothesis that the Jet of Tehuantepec influences monthly variability of lightning activity over the Tehuantepec sub-region by advection and dispersion of continental, anthropogenic particles. Because of the location and the shape of the Tehuantepec sub-region (see Fig. 1), the meridional wind component of the Jet of Tehuantepec would have a critical impact on aerosol particle dispersion and advection and resulting ambient concentration in this region. Note that the meridional wind component decreases from May to June, increases from June to July, doesn't change from July to August, decreases from August to September, and increases from September to October. This monthly variability in meridional wind com-

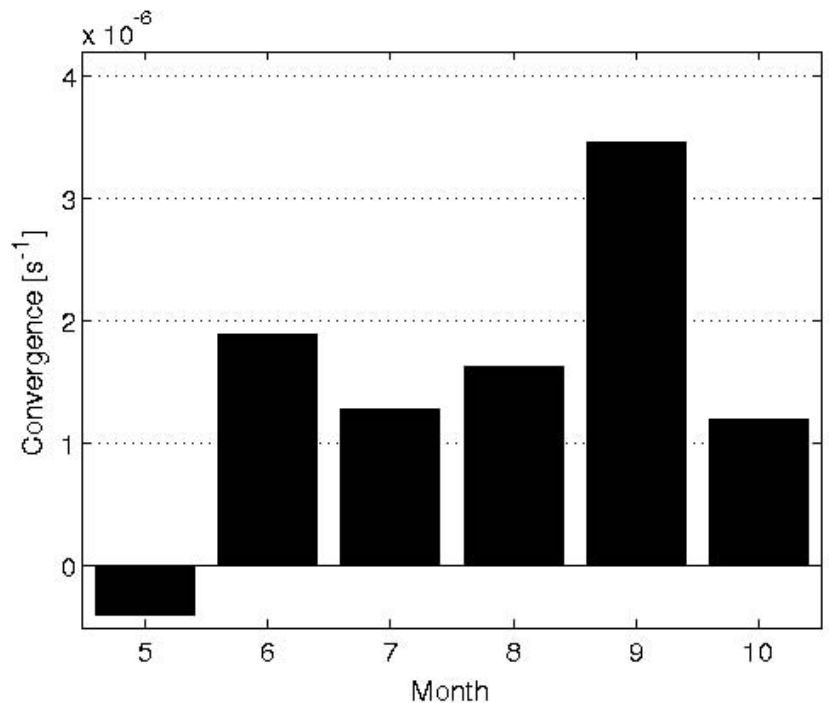

Fig. 11. Monthly variability of convergence averaged over the Tehuantepec Jet sub-region during the rainy seasons of years 2000 2009.

ponents coincides with the variability of monthly lightning flash density described above.

The influence of the Jet of Tehuantepec on lightning activity could be related to the dynamic conditions that the jet creates in the region and/or to the microphysical properties of aerosol particles advected from the continent to the ocean. In order to determine the role of dynamics, the monthly variability of horizontal convergence was calculated on a $0.5^{\circ} \times 0.5^{\circ}$ grid and averaged over the Tehuantepec subregion (Fig. 11). This resolution represents large mesoscale to synoptic scale convergence, so the results presented in Fig. 11 reflect basically the signal of the Jet of Tehuantepec. Note that the monthly distribution of convergence is opposite to that of lightning density. Low values of convergence in July and August are related to the mid-summer decrease in rainfall but not to lightning. Therefore wind convergence is not the factor that determines the variability of lightning activity over this area.

The diurnal variation of the winds in the Tehuantepec region can be analyzed only partially using QSCAT data, since the satellite passes covered this region generally within an hour, twice per day. At 00:00-01:00 UTC (18:00-19:00 LST), when the sea breeze acts in the opposite direction to the prevailing offshore winds, weak and divergent winds are registered (not shown). Stronger and convergent winds are observed at 12:00-13:00 UTC (06:00-07:00 LST), when the land breeze coincides with the direction of the prevailing winds. This is consistent with the observed diurnal cycle of flashes in the Tehuantepec Jet sub-region which shows maximum values at night and early morning and minimum values in the afternoon and early evening (see Fig. 7). 
In order to evaluate the effect of aerosols on lightning, measurements of particle concentrations are needed. At the moment, only satellite measurements of AOD are available for the areas and months of interest. During the rainy season, the aerosol data are scarce because of extended cloud coverage and particle scavenging by raindrops; therefore, $10 \mathrm{yr}$ of Terra satellite and $7 \mathrm{yr}$ of Aqua satellite records were averaged in order to obtain a climatological product. The monthly distributions of AOD for Tehuantepec and ITCZ sub-regions are shown in Fig. 12a and b, respectively.

Over both sub-regions, there is a pronounced maximum of AOD in May (Fig. 12a and b). This maximum is clearly related to the May AOD peak over continental Mexico (not shown) caused by biomass burning, which is most intense in the Yucatan Peninsula and on the Pacific coast (Yokelson et al., 2011). Note that the ITCZ sub-region is located more than a thousand kilometers away from the coastlines (see Fig. 1) and it is still affected by continental aerosol particles. The AOD peak in May over the ITCZ sub-region (Fig. 12b) is probably linked to the maximum in lightning activity in this month, shown in Fig. 9b. Also, the AOD maximum over the Tehuantepec sub-region in May (Fig. 12a) is probably related to the lightning activity peak observed at the beginning of the rainy season, which is unusually high when one takes into account the low value of rainfall (Fig. 9a). Moreover, the monthly variability of flash density over the Tehuantepec sub-region (Fig. 9a) is similar to that of AOD (Fig. 12a); there is an AOD minimum in June and September, although the variability is much less pronounced.

The hypothesis that offshore winds influence lightning activity through the transport of aerosol particles from the continent seems to be a consistent explanation for the results presented here. Baumgardner et al. (2005) concluded that the concentrations of condensation nuclei measured over the Gulf of Tehuantepec are highly dependent on wind direction and magnitude and it is also known that condensation nuclei have a strong effect on electrical activity in clouds. For example, Altaratz et al. (2010) analyzed the relationship between lightning strokes registered by the WWLLN and the AOD in the Amazonian region influenced by smoke from biomass burning. They showed that there is a range in the values of AOD where a small increase in particle loading results in a very strong enhancement of electrical activity. In a more recent study, Yuan et al. (2011) estimated that, over the West Pacific Ocean, a $60 \%$ increase in aerosol loading leads to more than $150 \%$ increase in lightning flashes.

In the present study we also find that the Tehuantepec sub-region of the Tropical Pacific exhibits more precipitation ice that the ITCZ sub-region, indicative of a larger role of cold-rain processes in the development of precipitation. The amount of precipitation ice is highly correlated with lightning flash density (Petersen et al., 2005). Continental clouds exhibit very large concentrations of ice particles, which can develop from ice nuclei (IN) or from other mixed-phase collision processes in the presence of large concentrations of a) Tehuantepec Jet sub-region

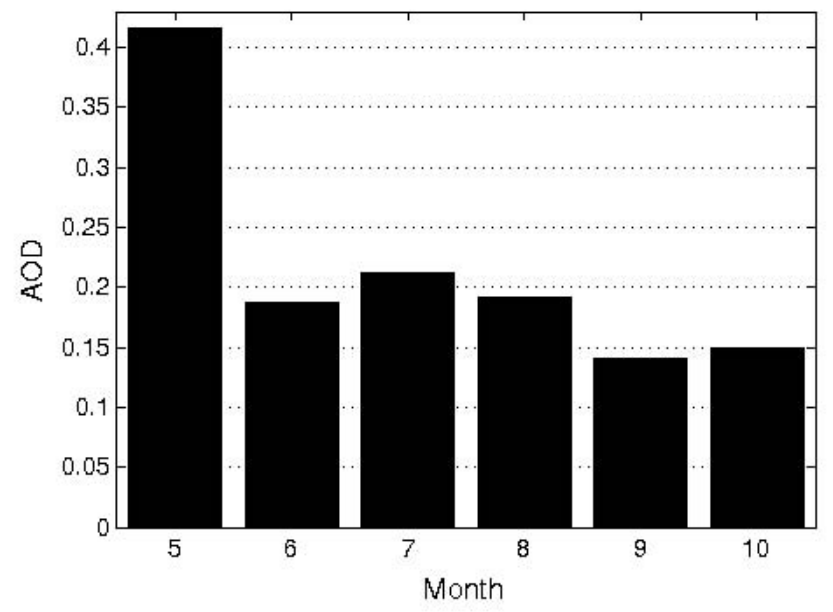

b) ITCZ subregion

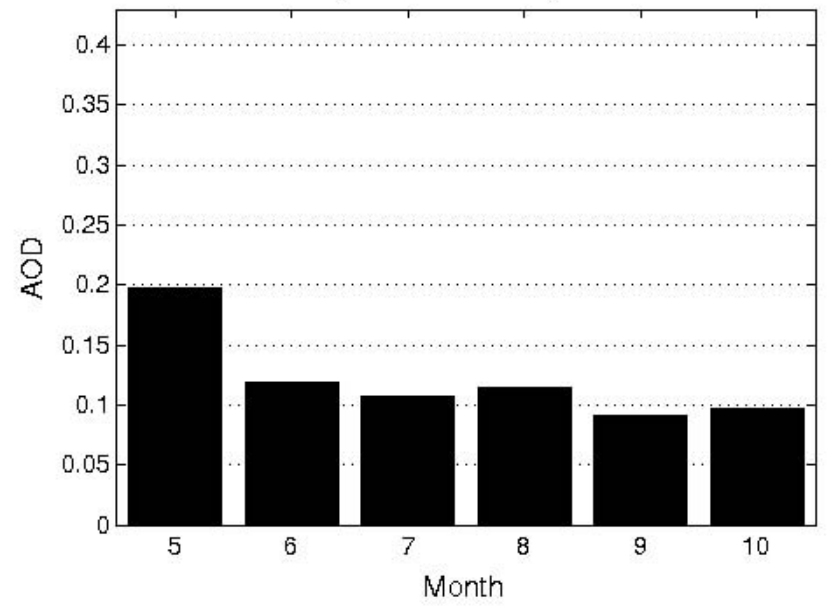

Fig. 12. Monthly variability of aerosol optical depth during rainy season averaged over the Tehuantepec Jet and the ITCZ sub-regions for years from 2000 to 2009 (Terra satellite) and from 2003 to 2009 (Aqua satellite).

small water droplets that result from large $\mathrm{CCN}$ concentrations. The continental CCN spectra generate cloud droplet spectra composed of many small particles which are not able to grow to precipitation size by the process of collisioncoalescence. Moreover, if a cloud forms in a polluted environment, there is a great release of latent heat which results in very strong updrafts (Van den Heever et al, 2006; Kucieńska et al., 2010a). Therefore, the clouds composed of small and numerous droplets do not generate warm precipitation; instead, the droplets are carried by the updrafts above the $0^{\circ} \mathrm{C}$ isotherm and participate in mixed-phase processes involved in charge separation. Hence, the high amounts of precipitation ice observed over coastal regions could be the result of the presence of $\mathrm{CCN}$ spectra of continental type. 
If the intensification of the Jet of Tehuantepec during midsummer has an impact on electrical activity through the increase of precipitation ice, then this increase is expected to be observed in the profiles of hydrometeors over the Tehuantepec sub-region. However, neither the precipitation ice profiles, nor the cloud top heights, retrieved from the TRMM 2A12 product, exhibit significant differences between both periods (June and September compared to July-August). The differences in precipitation ice water path are shown in Table 2. During night there is about $9 \%$ more precipitation ice in July and August than in June and September, however during daytime the precipitation ice is highest in June and lowest in September. The differences between both periods are too small to draw conclusions, especially when one takes into account the deficiencies of the TRMM 2A12 algorithm described in Sect. 3.2. However, the influence of CCN on lightning can be much more complex than only through its impact on ice amounts. Many other factors related to condensation nuclei could be involved. For example, the effect of CCN concentrations on updraft velocities could be a very important mechanism of influence on lightning activity, as it is known that flash densities are related to updraft speeds. Zipser and Lutz (1994) concluded that a necessary condition for rapid cloud electrification is that the updraft speed of a convective cell must exceed a threshold value. They estimated this threshold value as 6-7 $\mathrm{m} \mathrm{s}^{-1}$ for mean speed and 10-12 $\mathrm{m} \mathrm{s}^{-1}$ for peak speed. Another possible factor of influence of $\mathrm{CCN}$ concentration on lightning is through its impact on the supercooled liquid water content and size distribution of cloud droplets, as it was proven that these factors have an important role in the process of charge separation (e.g. Avila et al., 1999). The amount of supercooled water, retrieved from the TRMM $2 \mathrm{~A} 12$ product, is almost the same for the four months, but unfortunately there are no available data on droplet size distribution for this region during this period.

The results presented in this section indicate that continental aerosol particles advected by the Jet of Tehuantepec over Pacific areas could modulate electrical activity in addition to other factors that influence the development of thunderstorms over this region.

\subsection{Relation between daily data of aerosol optical depth and lightning}

Recent studies indicate that there is certain range in the AOD values for which a very strong positive impact of aerosol particles on lightning can be observed (Altaratz et al., 2010; Yuan et al., 2011). Continental aerosol particles transported by the Jet of Tehuantepec are expected to influence both rainfall (Koren et al., 2012) and lightning; however, high values of lightning registered during May (biomass burning period) and during midsummer (northern wind intensification) indicate that over this region the effect of aerosol particles on lightning could be larger than on rainfall. Also, light-
Table 2. Precipitation ice water path $\left[\mathrm{g} \mathrm{m}^{-2}\right]$ in Tehuantepec region during summer for day (06:00 a.m.-06:00 p.m.) and night (06:00 p.m.-06:00 a.m.).

\begin{tabular}{lrrrr}
\hline & June & July & August & September \\
\hline Day & 5.94 & 5.15 & 5.68 & 4.81 \\
Night & 4.88 & 5.33 & 5.34 & 4.96 \\
\hline
\end{tabular}

ning maximum registered in May over the ITCZ region located further away from the coast points toward the role of aerosols.

In addition to monthly variability of lightning and AOD, daily data were analyzed. However, daily series of AOD and lightning do not show a correlation between the magnitudes of both variables. An analysis of the impact of different ranges of AOD values on lightning density showed that the highest values of lightning were observed on days with moderate values of AOD (0.2-0.35). In Fig. 13, the difference between the average value of lightning observed on days with moderate AOD (0.2-0.35) and low AOD (0.05-0.15) is presented. The AOD values were derived from the MODIS instrument located on the sun-synchronous Aqua satellite, with overpasses at about 01:30 p.m. local time. The lightning flashes used to generate the figure were summed between 08:00 a.m. and 05:00 p.m. local time. The calculations were done for the year 2009, when the detection efficiency of WWLLN was the highest (within the analyzed period: 20052009) and the amount of data samples in each AOD range was sufficient to calculate lightning difference for most of the grid squares. White squares represent regions where the number of data samples was less than 8 for either one or two of the AOD ranges. The results presented in Fig. 13 show that there are more lightning flashes recorded on days with moderate AOD than on days with low AOD over the Tehuantepec sub-region, the Gulf of Mexico, continental Mexico and some areas of the ITCZ. However, the results change drastically when the difference between lightning recorded on days with high AOD (0.4-1.5) and moderate AOD (0.2-0.35) is calculated.

In contrast with the results in Fig. 13, the differences between lightning flashes on days with high and moderate AOD (Fig. 14) are negative for the Gulf of Tehuantepec, most of the Gulf of Mexico and regions of the Sierra Madre Occidental, close to the Pacific coast. These results indicate that very high values of AOD may decrease lightning and even inhibit it. The results presented in Figs. 13 and 14 show that the effect of AOD on lightning depends on the range of AOD and this fact is the reason why there is no direct correlation between the magnitudes of AOD and lightning in daily time series. Our results are in agreement with the results of Altaratz et al. (2010), who observed that in the regions affected by Amazonian fires, the lightning density increases when AOD 


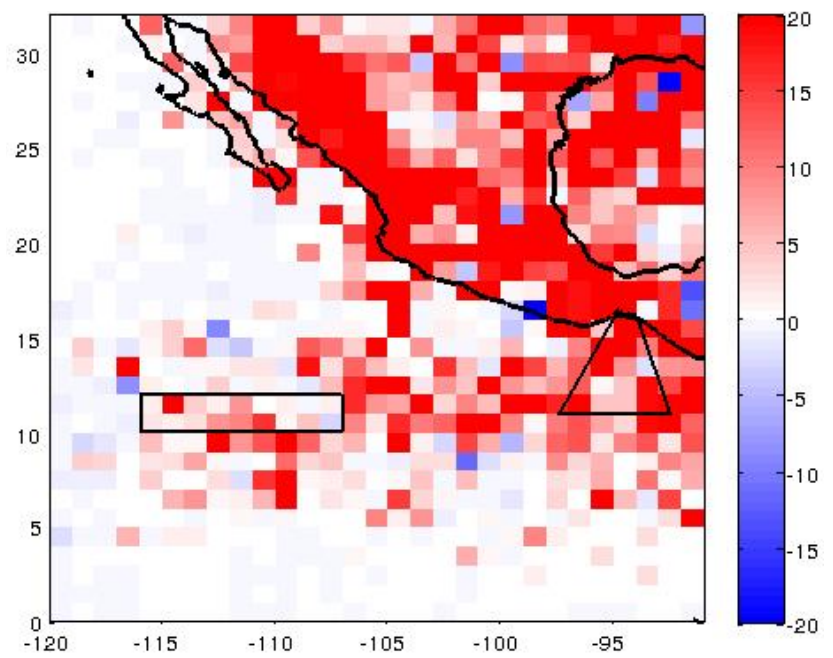

Fig. 13. Differences between average numbers of lightning flashes registered during days with moderate AOD (0.2-0.35) and low AOD (0.05-0.015).

increases for AOD values smaller than 0.35 and decreases for AOD larger than 0.4.

Among the analyzed years, 2007 was the only one that did not show a lightning peak in May. During most of the days of May 2007, the AOD was much higher than 0.4, and the average monthly value $(0.48)$ was the highest one among the analyzed years. These results suggest that the very high aerosol loading may have suppressed convection and lightning in May 2007.

Moreover, the results shown in Figs. 13 and 14 indicate that the increase of both lightning and AOD is not likely driven by the meteorological conditions, as the relation of proportionality between these two variables is only valid for a limited range of AOD. These results rather point toward the effect of aerosol particles on lightning density.

Although the above results indicate that there is a link between aerosols and electrical activity, the spatial distribution of lightning over the analyzed regions cannot be explained only by aerosol particles. For example, during summer there is a pronounced contrast between electrical activity over land and sea along the Pacific coast, with the highest flash density recorded over the sea (Kucieńska et al., 2010b), whereas the AOD values do not show such a contrast. The spatial distribution of lightning over this region is related to the topography of the mountain ranges that are located less than $100 \mathrm{~km}$ from the coast and reach $3000 \mathrm{~m}$ above mean sea level. The signals of highest rainfall and lightning over land occur very close to the coastline and are clearly related to the orographic forcing.

The contrast between land and sea in both precipitation and lightning is observed in their diurnal cycles, driven by land-sea and mountain-valley breezes (Kucieńska et al., 2012). The highest rainfall and electrical activity occur at

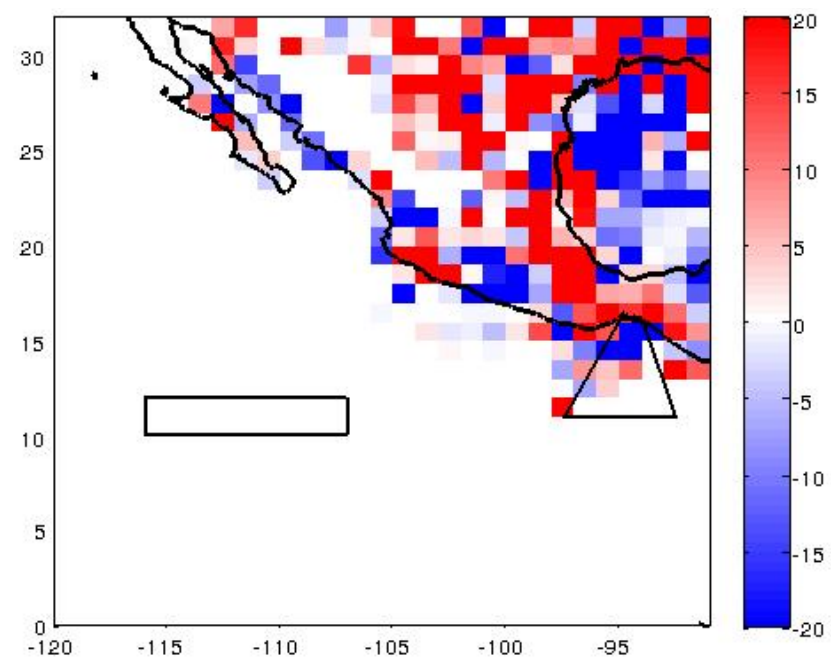

Fig. 14. Differences between average numbers of lightning flashes registered during days with high AOD (0.4-1.5) and moderate AOD (0.2-0.35).

night and early morning over the sea, when a large gradient in both variables is observed across the coastline.

The highest lightning density over land occurs near the coastline due to the topography; however, over the sea, very high lightning density is recorded hundreds of kilometers away from the coast, especially in the Jet of Tehuantepec region (Kucieńska et al., 2010b). The lightning distribution over this region could be influenced by aerosol particles advected by the Jet of Tehuantepec. It is also noteworthy that, although the lightning density changes significantly across the coastline, the number of flashes per rainfall does not (see Fig. 2).

\section{Summary and conclusions}

The relationships between lightning, rainfall, vertical profiles of hydrometeors and latent heating over oceanic regions adjacent to Mexican coastlines were analyzed in order to explore possible reasons for the very high lightning activity registered by the WWLLN. For certain coastal areas, the number of flashes per rainfall (FPR) over the seaside is found to be as high as or even higher than the FPR over land. Vertical hydrometeor profiles over the coastal oceanic areas with high lightning density exhibit characteristics similar to those of continental clouds: large precipitation ice content and an increased height range of coexistence of precipitation ice and cloud water.

The coastal area of the Tropical Pacific influenced by the Jet of Tehuantepec was analyzed in detail and it was found that the monthly variability of lightning over this sub-region is similar to the monthly variability of the meridional component of the wind, but it is not related to the variability of the wind convergence. An interesting characteristic of this 
sub-region is that the intensification of the Jet of Tehuantepec has opposite effects on rainfall and lightning: it decreases the former and increases the latter. The influence of the Jet of Tehuantepec on rainfall is associated with large scale dynamic conditions and local thermodynamic conditions (Magaña et al., 1999; Romero-Centeno et al., 2007). We explore here the hypothesis that the impact of the wind jet on lightning is related to the advection of aerosol particles from the continent.

The analysis of the characteristics of clouds, precipitation and lightning over the oceanic regions adjacent to Mexican coastlines indicates that the continental cloud condensation nuclei, and possibly also the ice nuclei, transported by offshore winds to the maritime coastal zones could have an important influence on lightning activity. The strong and steady winds associated with the Jet of Tehuantepec can transport particles for hundreds of kilometers, affecting the microphysics of the clouds that develop under such influence. Small and numerous continental CCN lead to the conditions that favor the development of electric field: stronger updrafts, higher ice contents, greater cloud vertical development and longer cloud lifetimes. Recent findings reported in the literature (i.e. Altaratz et al., 2010; Yuan et al., 2011) prove that changes in the concentrations of $\mathrm{CCN}$ have a great impact on the processes of cloud electrification, especially over oceanic regions.

It is also found that the impact of aerosols on lightning depends on the range of aerosol optical depth. The highest lightning for the analyzed regions is observed for AOD values between 0.2 and 0.35 . The AOD values higher than 0.4 tend to decrease and even suppress lightning for many Mexican regions.

Even though Petersen et al. (2005) argued that the very high correlation between precipitation ice and lightning flash density in cumulonimbus clouds is independent of regime (maritime, coastal and continental), we find that in fact there is a difference in this relationship in the eastern Tropical Pacific. In-situ observations by an instrumented aircraft during EPIC in September 2001, showed peak updrafts up to $17 \mathrm{~ms}^{-1}$ in convective clouds in the Tehuantepec sub-region about $600 \mathrm{~km}$ from the shore when the winds flowed from the continent to the ocean (Baumgardner et al., 2005). The estimated peak threshold for rapid cloud electrification of $10-12 \mathrm{~ms}^{-1}$ (Zipser and Lutz, 1994) is regularly exceeded in those clouds, precipitation forms by mixed-phase processes and the precipitation ice can be considered as an indicator of surface rainfall. However, there is an inverse relationship between rainfall and lightning density when there is advection of continental aerosols into the Tehuantepec sub-region.

In this study, the main arguments in favor of the hypothesis that relates strong lightning activity over the Tehuantepec sub-region to the $\mathrm{CCN}$ advected from the continent are the relationships between lightning density, intensity of the meridional wind component and mean aerosol optical depth observed over the area influenced by the Jet of Tehuantepec.
These three variables exhibit very similar monthly distributions.

The phenomenon of lightning is very complex since it is related to many physical processes occurring within spatial scales that range from micrometers to thousands of kilometers. This paper is aimed at indicating the possible reasons for exceptionally high lightning activity observed over certain oceanic areas and the analysis presented here are mainly qualitative. The relationships between variables analyzed in this study point toward the possible lines of further research that will contribute to deepen our understanding of lightning.

Acknowledgements. The authors wish to thank the World Wide Lightning Location Network (http://wwlln.net), collaboration among over 50 universities and institutions, for providing the lightning location data used in this paper. The TRMM data used in this work were acquired as part of the NASA's Earth-Sun System Division, archived and distributed by the Goddard Earth Sciences (GES) Data and Information Services Center (DISC) Distributed Active Archive Center (DAAC). The MODIS data were downloaded from http://ladsweb.nascom.nasa.gov/data/search.html. Partial funding for this study was available through grants PAPIIT IN105811-2, PAPIIT IA100612 and SEP-CONACYT 62071.

Edited by: J. Quaas

\section{References}

Abarca, S. F., Corbosiero, K. L., and Galarneau Jr., T. J.: An evaluation of the Worldwide Lightning Location Network (WWLLN) using the National Lightning Detection Network (NLDN) as ground truth, J. Geophys. Res., 115, D18206, doi:10.1029/2009JD013411, 2010.

Abarca, S. F., Corbosiero, K. L., and Vollaro, D.: The World Wide Lightning Location Network and Convective Activity in Tropical Cyclones, Mon. Weather Rev., 139, 175-191, 2011.

Adler, R. F., Huffman, G. J., and Keehn P. R: Global tropical rain estimates from microwave-adjusted geosynchronous IR data, Remote Sensing Reviews, 11, 125-152, 1994.

Altaratz, O., Koren, I., Yair, Y. and Price, C.: Lightning response to smoke from Amazonian fires, Geophys. Res. Lett., 37, L07801, doi:10.1029/2010GL042679, 2010.

Avila, E. E., Pereyra, R. G., Aguirre Varela, G. G., and Caranti, G. M.: The effect of the cloud droplet spectrum on electrical-charge transfer during individual ice-ice collisions, Q. J. Roy. Meteorol. Soc., 125, 1669-1679, 1999.

Barton, E. D., Argote, M. L., Brown, J., Kosro, P. M., Lavin, M., Robles, J. M., Smith, R. L., Trasviña, A., and Velez, H. S.: Supersquirt: Dynamics of the Gulf of Tehuantepec, Mexico, Oceanography, 6, 23-30, 1993.

Baumgardner, D., Raga, G. B., Jimenez, J. C., and Bower, K.: Aerosol particles in the Mexican East Pacific Part I: processing and vertical redistribution by clouds, Atmos. Chem. Phys., 5, 3081-3091, doi:10.5194/acp-5-3081-2005, 2005.

Baumgardner, D., Raga, G. B., Grutter, M., and Lammel, G.: Evolution of anthropogenic aerosols in the coastal town of Salina Cruz, 
Mexico: Part I particle dynamics and land-sea interactions, Sci. Total Environ., 367, 288-301, 2006.

Bell, T., Rosenfeld, L. D., and Kim, K.-M.: Weekly cycle of lightning: Evidence of storm invigoration by pollution, Geophys. Res. Lett., 36, L23805, doi:10.1029/2009GL040915, 2009.

Brennan, M. J., Cobb III, H. D., and Knabb, R. D.: Observations of Gulf of Tehuantepec gap wind events from QuikSCAT: An updated event climatology and operational model evaluation, Weather Forecast., 25, 646-658, 2010.

Chelton, D. B., Freilich, M. H., and Esbensen, S. K.: Satellite observations of the wind jets off the Pacific coast of Central America. Part I: Case studies and statistical characteristics, Mon. Weather Rev., 128, 1993-2018, 2000.

Chelton, D. B., Schlax, M. G., Freilich, M. H., and Milliff, R. F.: Satellite measurements reveal persistent small-scale features in ocean winds, Science, 303, 978, doi:10.1126/science.1091901, 2004.

Chui, L. and Chang, A.: Oceanic Rain Column Height Derived from SSM/I, J. Climate, 13, 4125-4136, 2000.

Curtis, S.: Diurnal cycle of rainfall and surface winds and the midsummer drought of Mexico/Central America, Clim. Res., 27, 1$8,2004$.

Gopalan, K., Wang, N.-Y., Ferraro, R., and Liu, C.: Status of the TRMM 2A12 Land Precipitation Algorithm, J. Atmos. Ocean. Tech., 27, 1343-1354, doi:10.1175/2010JTECHA1454.1, 2010.

Higgins, W., Ahijevych, D., Amador, J., Barros, A., Berbery, E. H., Caetano, E., Carbone, R., Ciesielski, P., Cifelli, R., CortezVazquez, M., Douglas, A., Douglas, M., Emmanuel, G., Fairall, C., Gochis, D., Gutzler, D., Jackson, T., Johnson, R., King, C., Lang, T., Lee, M. I., Lettenmaier, D., Lobato, R., Magana, V., Meiten, J., Mo, K., Nesbitt, S., Ocampo-Torres, F., Pytlak, E., Rogers, P., Rutledge, S., Schemm, J., Schubert, S., White, A., Williams, C., Wood, A., Zamora, R., and Zhang, C.: The NAME field campaign and modeling strategy, B. Am. Meteorol. Soc., 87, 79-94, 2006.

Khain, A., Cohen, N., Lynn, B., and Pokrovsky, A.: Possible Aerosol Effects on Lightning Activity and Structure of Hurricanes, J. Atmos. Sci., 65, 3652-3677, doi:10.1175/2008JAS2678.1, 2008.

Koren, I., Altaratz, O., Remer, L. A., Feingold, G., Martins, J. V., and Heiblum, R. H.: Aerosol-induced intensification of rain from the tropics to the mid-latitudes, Nature Geosci., 5, 118-122, doi:10.1038/ngeo1364, 2012.

Kucieńska, B., Montero-Martínez, G., and García-García, F.: A simulation of the influence of organic and inorganic pollutants on the formation and development of warm clouds over Mexico City, Atmos. Res., 95, 487-495, 2010a.

Kucieńska, B., Raga, G. B., and Rodríguez, O.: Cloud-to-ground lightning over Mexico and adjacent oceanic regions: a preliminary climatology using the WWLLN dataset, Ann. Geophys., 28, 2047-2057, doi:10.5194/angeo-28-2047-2010, 2010b.

Kucieńska, B., Raga, G. B., and Torres-Puente, V.: Climatology of precipitation and lightning over the Pacific coast of southern Mexico retrieved from Tropical Rainfall Measuring Mission satellite products and World Wide Lightning Location Network data, Int. J. Remote Sens., 33, 2831-2850, doi:10.1080/01431161.2011.621905, 2012.

Kummerow, C. and Barnes, W., The Tropical Rainfall Measuring Mission (TRMM) sensor package, J. Atmos. Ocean. Tech., 15,
809-816, 1998.

Kummerow, C., Olson, W. S., and Giglio, L.: A simplified scheme for obtaining precipitation and vertical hydrometeors profiles from passive microwave sensors, IEEE Transactions on Geoscience and Remote Sensing, 34 pp. 1213-1232, 1996.

Kummerow, C., Simpson, J., Thiele, O., Barnes, W., Chang, A. T. C., Stocker, E., Adler, R. F., Hou, A., Kakar, R., Wentz, F., Ashcroft, P., Kozu, T., Hong, Y., Okamoto, K., Iguchi, T., Kuroiwa, H., Ime, E., Haddad, Z., Huffman, G., Ferrier, B., Olson, W. S., Zipser, E., Smith, E. A., Wilheit, T. T., North, G., Krishnamurti, T., and Nakamura, K.: The status of the Tropical Rainfall Measuring Mission (TRMM) after two years in orbit, J. Appl. Meteorol., 39, 1965-1982, 2000.

Kummerow, C., Hong, Y., Olson, W. S., Yang, S., Adler, R. F., McCollum, J., Ferraro, R., Petty, G., Shin, D.-B., and Wilheit, T. T.: The Evolution of the Goddard Profiling Algorithm (GPROF) for Rainfall Estimation from Passive Microwave Sensors, J. Appl. Meteor., 40, 1801-1820, doi:10.1175/15200450(2001)040;1801:TEOTGP ¿2.0.CO;2, 2001.

Magaña, V., Amador J. A., and Medina, S.: The midsummer drought over Mexico and Central America, J. Climate, 12, 1577 1588, 1999.

Masunaga, H., Iguchi, T., Oki, R., and Kachi, M.: Comparison of Rainfall Products Derived from TRMM Microwave Imager and Precipitation Radar, J. Appl. Meteor., 41, 849-862, doi:10.1175/1520-0450(2002)041;0849:CORPDF $i 2.0 . C O ; 2$, 2002.

Nesbitt, S., Zipser, E., and Cecil, D.: A Census of Precipitation Features in the Tropics Using TRMM: Radar, Ice Scattering, and Lightning Observations, J. Climate, 13, 4087-4106, 2000.

Nesbitt, S. W., Zipser, E. J., and Kummerow, C. D.: An examination of version 5 rainfall estimates from the TRMM microwave imager, precipitation radar, and rain gauges on global, regional and storm scales, J. Appl. Meteor., 43, 1016-1036, 2004.

Nesbitt, S., Gochis D. J., and Lang, T.: The Diurnal Cycle of Clouds and Precipitation along the Sierra Madre Occidental Observed during NAME-2004: Implications for Warm Season Precipitation Estimation in Complex Terrain, J. Hydrol., 9, 728-743, 2008.

Petersen, W. A. and Rutledge S. A.: On the relationship between cloud-to-ground lightning and convective rainfall, J. Geophys. Res., 103, 14025-14040, doi:10.1029/97JD02064, 1998.

Petersen, W., Cifelli, R., Boccippio, D., Rutledge, S., and Fairall, C.: Convection and Easterly Wave Structures Observed in the Eastern Pacific Warm Pool during EPIC-2001, J. Atmos. Sci, 60, 1754-1773, 2003.

Petersen, W. A., Christian, H. J., and Rutledge, S. A.: TRMM observations of the global relationship between ice water content and lightning, Geophys. Res. Lett., 32, L14819, doi:10.1029/2005GL023236, 2005.

Rodger, C. J., Brundell, J. B., and Dowden, R. L.: Location accuracy of VLF World-Wide Lightning Location (WWLL) network: Post-algorithm upgrade, Ann. Geophys., 23, 277-290, doi:10.5194/angeo-23-277-2005, 2005.

Romero-Centeno, R., Zavala-Hidalgo, J., Gallegos, A., and, O'Brien, J. J.: Isthmus of Tehuantepec wind climatology and ENSO signal, J. Climate, 16, 2628-2639, 2003.

Romero-Centeno, R., Zavala-Hidalgo, J., and Raga, G. B.: Midsummer gap winds and low-level circulation over the eastern tropical 
Pacific, J. Climate, 20, 3768-3784, 2007.

Rosenfeld, D., Lohmann, U., Raga, G. B., O’Dowd, C., Kulmala, M., Fuzzi, S., Reissell, A., and Andreae, M.: Flood or drought: How do aerosols affect precipitation?, Science, 321, 1309-1313, 2008.

Saunders C.: Charge separation mechanisms in clouds, Space Sci. Rev., 137, 335-353, 2008.

Schultz, D. M., Bracken, W. E., Bosart, L. F., Hakim, G. J., Bedrick, M. A., Dickinson, M. J., and Tyle, K. R.: The 1993 superstorm cold surge: Frontal structure, gap flow, and tropical impact, Mon. Weather Rev., 125, 5-39, Corrigendum, 125, 662, 1997.

Sherwood, S. C., Phillips, V. T. J., and Wettlaufer, J. S.: Small ice crystals and the climatology of lightning, Geophys. Res. Lett., 33, L05804, doi:10.1029/2005GL025242, 2006.

Short, D. and Nakamura, K.: TRMM Radar Observations of Shallow Precipitation over the Tropical Oceans, J. Climate, 13, 41074124, 2000.

Takahashi, T.: Riming electrification as a charge generation mechanism in thunderstorms, J. Atmos. Sci., 35, 1536-1548, 1978.

Takayabu, Y. N.: Rain-yield per flash calculated from TRMM PR and LIS data and its relationship to the contribution of tall convective rain, Geophys. Res. Lett., 33, L18705, doi:10.1029/2006GL027531, 2006.

Tao, W.-K. and Adler, R. (Eds.), Cloud Systems, Hurricanes, and the Tropical Rainfall Measuring Mission (TRMM). Part V. TRMM-History and Management, Meteorological Monographs, 29, 175-234 (Boston: American Meteorological Society), 2003.
Wang, N-Y., Liu, C., Ferraro, R., Wolff, D., Zipser, E., and Kummerow, C.: TRMM 2A12 land precipitation product - Status and future plans, J. Meteor. Soc. Japan, 87A, 237-253, 2009.

Williams, E. and Stanfill, S.: The physical origin of the landocean contrast in lightning activity, Comptes Rendus Physique, 3, 1277-1292, 2002.

Van den Heever, S. C., Carrió, G. G., Cotton, W. R., DeMott, P. J., and Prenni, A. J.: Impacts of nucleating aerosol on Florida storms. Part I: mesoscale simulations, J. Atmos. Sci., 63, 17521775, 2006.

Yokelson, R. J., Burling, I. R., Urbanski, S. P., Atlas, E. L., Adachi, K., Buseck, P. R., Wiedinmyer, C., Akagi, S. K., Toohey, D. W., and Wold, C. E.: Trace gas and particle emissions from open biomass burning in Mexico, Atmos. Chem. Phys., 11, 67876808, doi:10.5194/acp-11-6787-2011, 2011.

Yuan, T., Remer, L. A., Pickering, K. E., and Yu, H.: Observational evidence of aerosol enhancement of lightning activity and convective invigoration. Geophys. Res. Lett., 38, L04701, doi:10.1029/2010GL046052, 2011.

Zipser, E. J.: Deep Cumulonimbus Cloud Systems in the Tropics with and without Lightning, Mon. Weather Rev., 122, 1837$1851,1994$.

Zipser, E. J. and Lutz, K. R.: The Vertical Profile of Radar Reflectivity of Convective Cells: A Strong Indicator of Storm Intensity and Lightning Probability?, Mon. Weather Rev., 122, 17511759, 1994. 